\title{
Polish Music Published by Moeck 1958 to 1967 - a (Failed?) Transfer from East to West
}

DOI: $10.14746 / \mathrm{rfn} .2020 .21 .4$

\section{INTRODUCTION}

In respect of the international reputation of Polish contemporary music during the 1960s, again and again in the specialist literature we find hints and traces as to when and where a worldwide successful work was published. But the relationship between composers and music publishers is only very rarely the object of investigation in current music analytical, historical and sociological research. In fact, the business of publishing musical works usually takes place less impressively 'behind the curtain' of spectacular concert events and thus often surprising musical-artistic aspects. And what happens if an Iron Curtain also stands between?

The article engages with exactly this topic. The changes in the musical-cultural life in Poland after 1956 and the genesis of contemporary music in the 1960s unquestionably had an impact on the catalogues of Polish, but also other publishing houses in 'Western' countries. Because of the dynamic development of West German musical life after 1945, in a way comparable to the new situation of Polish musical life after 1956, a German publishing house also gained prominence in dealing with Polish composers and the only state music publishing house at this time. However, despite the spirit of optimism that was spreading on both sides, there were also problems. The West German publisher acted according to the criteria of 'Western' market economy, while the Polish state institutions acted on the criteria of 'Eastern' planned economy and cultural policy decisions, made in the context of the so called 'Polish path to socialism'. Between 1958 and 1966, various interests came together in this context, resulting not only in an atmosphere of new beginnings, but also in a potential for problems and conflicts. This article therefore deals with the beginnings of the Polish export strategy of Polish contemporary music in connection with its (early) publishing in West Germany. On the one hand, the article refers to copyright disputes, which indicate how different the interests and scopes of action were. On the other hand, the article goes into details of the cooperation. A concrete issue here relates to the attempts to transfer Polish lyrical texts in vocal works into German and English. In fact, the difficulties arising from the relationship between text and music make it clear that here was a kind of limit of cultural transfer.

The content of the article is based on findings that I gathered in the context of my dissertation project at the Folkwang University of Arts in Essen. Generally speaking, the research primarily deals with the German-Polish interrelations in contemporary musical life of the 1960s. It concerns the participation of 
Polish composers in the West German concert scene, the role of music publishers in the context of the growing international reputation of (selected) Polish composers, but also the interest of German music cultural operators in Polish musical life. The research is based on a broad collection of source materials that I have collected in music archives such as the private one of the company Moeck Musikinstrumente + Verlag $\mathrm{GmbH}$ in Celle, that of the Academy of Art in Berlin, of the International Music Institute in Darmstadt likewise the archive of the Polish Composers Union in the Polish Information Center (POLMIC) as well as the Institute of National Remembrance in Warsaw and of the State Archive in Cracow. Statements from all these archives make a contribution, originating from the correspondence between relevant people and institutions on the German or the Polish side. In addition, the article also contains references to music magazines such as "Ruch Muzyczny".

\section{NEW CONDITIONS FOR THE POLISH MUSICAL LIFE}

One of the consequences of the Polish October 1956 was the change of social conditions in the People's Republic of Poland in relation to the Soviet Stalinist guidelines, and a more open cultural policy line under the new government leader of the Polish United Workers' Party, Władysław Gomułka (1905-1982). This process included not only a reorganisation of cultural life, but also a revision of cross-border travel regulations. As a result, leading cultural actors could now travel to Western European countries like Italy, France, Switzerland, Austria, the Benelux countries, England and some Scandinavian countries (as well as North and South American states). And as is well known, this step was fundamental to the establishing of the International Festival of Contemporary $\mathrm{Mu}-$ sic 'Warszawska Jesien'' ['Warsaw Autumn'] and its function as a place of 'transnational exchange', as well as the general development of the Polish contemporary orchestral and electroacoustic musical life. All in all the festival, which was held despite the political turbulences for the first time in Warsaw in October 1956, not only symbolized a statement against the former dominant Soviet cultural doctrine of Socialist
Realism, but also offered previously unknown room for manoeuvre for composers, musicians and other actors in the music-cultural environment. Involved in this process of a reorganisation of the entire Polish music business were, for example, concert halls, opera houses, the Polskie Radio (i Telewizja) [Polish Broadcasting Company] and the then entirely state-owned music publisher Polskie Wydawnictwo Muzyczne (PWM). Finally, the successes of Polish composers and their musical works since the late 1950s in their country and at music festivals abroad, gaining reputation also at the international level, also helped the Polish socialist leadership to enhance their new (foreign) cultural profile.

\section{POLISH AVANT-GARDE IN TOUCH WITH THE WEST GERMAN MUSICAL LIFE}

While the most important musical impulses in the interwar period came from Vienna and Paris, the international musical life after 1945 was spread over several centres like London, Milan, New York and Tokyo. No less well-known among today's music experts is the fact that the contemporary musical life of the Federal Republic of Germany became a focus of Polish musical operators, too. Similar to the situation in Poland after 1956 (albeit not directly comparable), West German cultural life also underwent a quintessential reorganization in the post-war period. In relation to this and along the intention of the Western Allies to support freely designed cultural and scientific activities as a part of denazification and re-education policy after 1945, also the self-employed organisation of contemporary musical life constituted an important part. In this context, the International Summer Courses for New Music in Darmstadt, of course, played a central role in the development of the West German contemporary orchestral and electroacoustic music life. From 1957 onwards, after Luigi Nono (1924-1990) invited participation, the up-coming Polish musicians like Tadeusz Baird (1928-1981), Włodzimierz Kotoński (1925-2014), Kazimierz Serocki (1922-1981) and Witold Szalonek (1927-2001) took advantage of the offer. They met here, for example, characters like Karlheinz Stockhausen (1928-2007), Pierre Boulez (1925-2016), Luciano Berio (1925-2003), György 
Ligeti (1923-2006) and John Cage (1912-1992) in person. Like the Warsaw Autumn on Polish soil, also the 'transnational character' of the Summer Courses brought together musicians, conductors, composers, music critics and journalists and many other cultural actors from all over the world - transcending the geographical, ideological and political boundaries of the East-West conflict. The Summer Courses, as it were, became a reference point in two different respects: The music concepts presented here seemed to be for some musicians like a 'Mecca of New Music' (at first), but they also evoked a rather critical attitude among others. Apart from Baird this in particular applies to Bogusław Schaeffer (1929-2019) and Witold Lutosławski (1913-1994). Many of the composers felt inspired by Edgar Varèse (1883-1965), Olivier Messiaen (1908-1992), Pierre Schaeffer (1910-1995) and the French musical tradition (as it has been important for Polish musical life since the interwar period) instead.

In this context, the musical pedagogical importance of Nadia Boulanger (1887-1979) with whom a number of Polish composers were studying both before and after the Second World War, should not be ignored. Also, as counterparts to the 'sound-related' music of France, the 'rational' compositional approaches of the so called 'Darmstadt School' were discussed and criticized in leading music journals such as "Ruch Muzyczny", "Res Facta" and "Muzyka" since 1957. And their (i. e. 'Darmstadt School') techniques and concepts were also reflected by composers in a practical way in their works henceforth ${ }^{2}$. Along the common definition of cultural transfer processes ${ }^{3}$,

J. Zathey, Darmstadt "Mekka Nowej Muzyki", "Ruch Muzyczny" 1957 no 12, pp. 9-13; idem, "Ruch Muzyczny" 1957 no 13, pp. 25-28; D. Cichy, Internationale Ferienkurse für Neue Musik w Darmstadcie. Dzieje, rola i znaczenie w myśli teoretycznej, praktyce kompozytorskiej i życiu muzycznym drugiej połowy XX wieku, Kraków 2009, p. 154; S. Borchers, Von Warschau nach Darmstadt und zurück. Lutosławski, Penderecki, Górecki und die Neue Musik, "Osteuropa" 2012 62. Jahrgang no 11-12, pp. 76-77. Comp.: https://internationales-musikinstitut.de/content/uploads/imd-1946-66chronikdarmstaedterferienkurse.pdf (3.07.2020).

2 Comp. D. Cichy, Internationale Ferienkurse für Neue Musik..., op. cit., pp. 152-163; R. Seehaber, Die "polnische Schule" in der Neuen Musik. Befragung eines musikhistorischen Topos, ed. D. Altenburg, Köln-Weimar-Wien 2009, pp. 90-94.

3 H.-J. Lüsebrink, Kulturtransfer - methodisches Modell und Anwendungsperspektiven, [in:] Europäische Integration als Prozess von Angleichung und Differenzierung, ed. I. Tömmel, Opladen 2001, pp. 216-217. this can be explained in a few steps: even though it was already used in the style of the Vienna School by Józef Koffler (1896-1944) and can also be found as a 'neoclassical dodecaphonic type' ${ }^{\text {' }}$ in works by the young Kazimierz Serocki (1922-1981), who already 'stretch[ed] the boundaries of the socialist-realist dictates by including [...] twelve-note techniques [...] [and] twelve-note arpeggio patterns ${ }^{3}$, the composers first adapted such almost unknown compositional techniques as dodecaphony and the derived from it serialism, punctualism as well as aleatoric methods. Then, in a second step, they modified them, combined them with their own stylistic points, linking them to the European and Polish music tradition, and a few years later presented new sound concepts - without necessarily having to rely on 'Darmstadt'.

As is also well known, this process led to the much-debated term 'Polska szkoła kompozytorska' ['Polish school of composers']. In 2009 a German musicology study by the musicologist Ruth Seehaber, for example, applied this term on the level of reception history and analytical investigations of selected musical works. One of the findings is based on a circle of composers who were named most often in the context of Polish and West German music-critical reviews since the late $1950 s^{6}$. One result of this study includes the following twelve 'protagonists of Polish New Music'?: Grażyna Bacewicz (1909-1969), Tadeusz Baird (1928-1981), Andrzej Dobrowolski (1921-1990), Henryk Mikołaj Górecki (1933-2010), Wojciech Kilar (1932-2013), Włodzimierz Kotoński (19252014), Witold Lutosławski (1913-1994), Krzysztof Penderecki (1933-2020), Bogusław Schaeffer (19292019), Kazimierz Serocki (1922-1981), Bolesław Szabelski (1896-1979) and Witold Szalonek (1927-2001). Due to the individual use of methods, different concepts and heterogeneous sound results of all these characters, Seehaber came to the conclusion that the term 'Polish school' in contemporary music should, rather, be understood as 'a collective term for the Polish composers of the 1950s to the 1970s, whose

\footnotetext{
4 Comp. J. Paja-Stach, Polish Music from Paderewski to Penderecki, Kraków 2010, pp. 108-112.

5 Comp. A. Thomas, Polish Music since Szymanowski, Cambridge 2005, p. 64 .

6 Comp. R. Seehaber, Die "polnische Schule"..., op. cit., pp. 35-80.

7 Comp. ibidem, p. 138, pp. 255-257.
} 
genesis was influenced by stylistic peculiarities as well as biographical similarities and historical conditions' ${ }^{8}$. In fact, this phenomenon also refers to other cultural areas at that time, which are reflected in descriptions of the so-called 'Polska szkoła jazzu [Polish school of jazz]', 'Polska szkoła filmowa [Polish school of film]' or 'Polska szkoła plakatu [Polish school of posters]'. Here also the aspect of new stylistic freedom endowed with a national cultural habitus and embedded in a transnational cultural exchange came into play (in contrast to the former Stalinist cultural policy) after 1956. These, as well as contemporary music, came to be integrated into the cultural life of the Federal Republic of Germany during the 1960s'.

Alongside the Summer Courses in Darmstadt, the Donaueschinger Musiktage für zeitgenössische Tonkunst [Donaueschingen Festival for contemporary music], organized by the Südwestfunk (SWF) and its musical director Heinrich Strobel (1898-1970), the President of the ISCM at the same time, also constituted a significant point of reference for some of the composers mentioned here. Several works, above all those by the young Penderecki, supported by Strobel with numerous premieres and commissions, were present at this forum, from 1959 onwards ${ }^{10}$. However, less known is the fact that their participation in West German musical life, beside Darmstadt and Donaueschingen, reached much deeper: on the level of the decentralized cultural life in all the German federal states, their presence extended also to publicly funded municipal orchestras and, to a greater extent, to big broadcasting companies with their concert series. Also, from 1959 onwards, for example, the

8 Ibidem, p. 133. German orig. text: 'als Sammelbegriff für die polnischen Komponisten der 50er bis 70er Jahre, zu dessen Genese so wohl stilistische Besonderheiten als auch biographische Gemeinsamkeiten und historische Rahmenbedingungen führten'.

9 Comp. C. Schmidt-Rost, Jazz in der DDR und Polen. Geschichte eines transatlantischen Transfers, Frankfurt am Main 2015, pp. 87214; M. Haltof, Historical Dictionary of Polish Cinema, second edition, Lanham 2015, pp. 188-192; V. Walter, Die deutsch-polnischen Kulturbeziehungen Bestandsaufnahme und Empfehlungen, ed. Institut für Auslandsbeziehungen e.V., ifa Dokument 2003 vol. 1, pp. 45-66; J. Harder, Polnische Filmplakate aus transnationaler Sicht. Die Wurzeln der "Polnischen Schule der Plakatkunst" in den 1950er Jahren, "Comparativ" 2014 vol. 24 no 4, pp. 58-67. Idem, Polnische Plakatkunst als Medium transnationaler Kunstkontakte und Kulturpolitik im OstWest-Konflikt, [in:] Themenportal Europäische Geschichte, 2015, www. europa.clio-online.de/essay/id/fdae-1656 (3.07.2020).

${ }_{10}$ R. Seehaber, Die "polnische Schule"..., op. cit., p. 29. concert series Musik der Zeit [Music of the time] became a welcoming address for the performance of contemporary Polish music. It was provided by the head of the department of contemporary music at Westdeutscher Rundfunk (WDR) in Cologne, Otto Tomek (1928-2013), who also commissioned Penderecki's Passio et mors Domini nostri Iesu Christi secundum Lucam for soprano, baritone and bass solo, narrator, children's choir, three mixed choirs and orchestra (1963-66). Without the personal commitment of Tomek, who placed the first performance of this oratorio in these series during the 700th anniversary celebrations of the cathedral of Münster (North Rhine-Westphalia) in March 1966, the performance of Penderecki's key work certainly would have been unthinkable ${ }^{11}$. However, other concert series, such as Das Neue Werk [the new work], held by the Norddeutscher Rundfunk (NDR) in Hamburg under the direction of Herbert Hübner (1903-1989), and the Musica Viva festival in Munich, which was initiated by Karl Amadeus Hartmann (1905-1963) and the Bayerischer Rundfunk (BR), were also significant in this context ${ }^{12}$. All in all, especially the music by Lutosławski, Baird and Penderecki could be heard in West German music life between the years 1957 and 1967 (see Fig. 1). Apart from Kilar, the number of all concerts with the music of these composers reached its climax (apparently ${ }^{13}$ ) in 1966 (see Fig. 2).

11 O. Tomek, [carbon copy of a] letter [to K. Penderecki], music archive 149, Otto Tomek, Akademie der Künste Berlin, without place, the 17. January 1964; K. Penderecki letter [to O. Tomek], archive 149, A. d. K. Berlin, Kraków, the 17. November 1964; comp. D. Gwizdalanka, Lutosławski. Błędy i legendy, "Ruch Muzyczny" 2013 no 19, pp. 38-42.

12 Comp. S. Borchers, Wglad do polsko-niemieckiej relacji $w$ muzyce współczesnej w sześćdziesiątych i siedemdziesiątych latach, [in:] W kręgu kultury PRL. Muzyka. Konteksty, ed. D. Skotarczak and K. Bittner, Poznań 2016, p. 82; S. Borchers, Von Warschau nach Darmstadt und zurück..., op. cit., pp. 79-80; comp. also R. Seehaber, Die "polnische Schule"..., op. cit., pp. 26-33.

${ }_{13}$ The results are based on the findings of a Microsoft Access database I've created. The figures cannot be considered as absolute values and can only be seen as a guideline. The example includes 511 works by the twelve composers I summarized at 414 different events (at concert series, individual concerts etc. performed, produced or radio-broadcasted works), which I filtered out between 1957-67 (latest update: May 2019). Its information is based on concert programmes (flyers, booklets, books), music chronicles in magazines such as "Ruch Muzyczny” (1957-1967), "Polish Music/ Polnische Musik" (19661967) and "Polska" (1960-1967) [the West German export edition of the monthly bulletin "Polska"] as well as the announcements of the publisher Moeck (1959-1967). Depending on the accuracy and the 


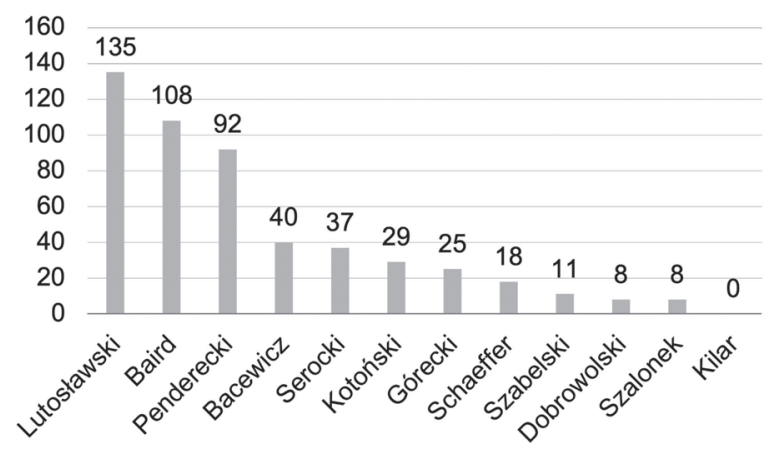

Fig. 1. Distribution of performed works (concerts, radio productions and recordings) among the 12 selected composers in the Federal Republic of Germany 1957-1967.

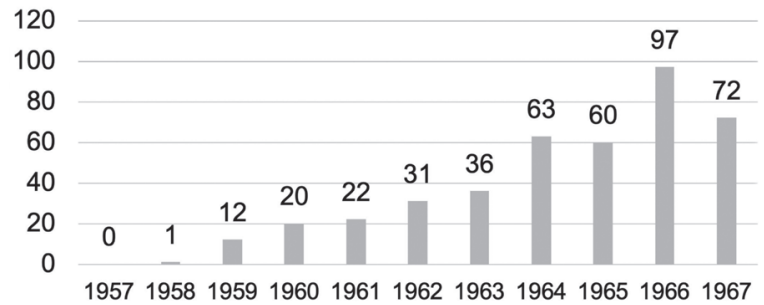

Fig. 2. Number of events (concerts, radio productions and recordings) with works by the 12 selected Polish composers in the Federal Republic of Germany (1957-1967).

Incidentally it should also be noted that first-class conductors such as Henryk Czyż (1923-2003), who conducted the premiere of Penderecki's St. Luke Passion, Jan Krenz (1926-2020), Andrzej Markowski (1924-1986) and Witold Rowicki (1914-1989), as well as soloists such as Andrzej Hiolski (1922-2000), Bernard Ładysz (1922-2020), Wanda Wiłkomirska (1929-2018) and Stefania Woytowicz (1922-2005) or even outstanding orchestras such as the Warsaw State Philharmonic and the Polish Radio Orchestra from Katowice, were from time to time involved in the numerous performances of Polish new music in West Germany ${ }^{14}$. Conversely, and naturally (but not with the same intensity and primarily centered on Warsaw), composers, musicians,

type of entries I summarized two or more concerts (from... to...) as single events. Therefore, the real number of concerts and performed works is variably higher.

14 S. Borchers, Von Warschau nach Darmstadt und zurück..., op. cit., p. 75 . soloists and ensembles belonging to the musical life of West (and East) Germany also participated in the Warsaw Autumn ${ }^{15}$. It should be noted here that the proportion of West German guests (in comparison to all guests from the 'capitalist countries') was by far the highest between 1958 and $1968^{16}$.

Apart from the promotion by radio stations, the cooperation with West German music publishers (which took place more in the background of the concert life) was equally important for the international spread of Polish contemporary works, and with it the worldwide reputation of the aforementioned circle of composers: since 1966, for example, the renowned publishing house B. Schott's Söhne has represented the extensive repertoire of all works by Penderecki, who unfortunately died recently ${ }^{17}$. From the early 1970 s also C. F. Peters in Frankfurt am Main (the equivalent of the renowned house of Peters in Leipzig, in the GDR nationalized as VEB Litolff/Edition Peters) put some works by Baird in its Edition Peters under contract. Sonoton Music GmbH \& Co. KG followed a little later in Munich. In cooperation with the music publishing editorial office of the Agencja Autorska [Authors' Agency], which was established in 1964 in Warsaw, Sonoton published (also among many other Polish authors) works by Szalonek, Augustyn Bloch (1929-2006) and Krzysztof Meyer (1943-) in its edition Pro Nova. Since the early 1980s Meyer has mainly been represented by the International Music Publishers Hans Sikorski in Hamburg. Sikorski also provides the catalogues of Edition Wilhelm Hansen and Chester Music Ltd. in Germany today. The programme also includes works by Górecki and Lutosławski. The latter composer enforced his exclusive representation by the Danish Wilhelm Hansen Musik-Forlag from the summer of $1966^{18}$, before it was later taken over by the internationally well-connected London music publishing house Chester.

15 Ibidem, pp. 86-87.

16 Comp. Z. Lissa, Analiza repertuaru "Warszawskich Jesieni", "Muzyka" 1969 vol. 14 no. 3, p. 65; S. Borchers, Wglad do polsko-niemieckiej relacji $w$ muzyce współczesnej..., op. cit., p. 87.

17 K. Penderecki, letter [to H. Moeck], folder Briefwechsel Penderecki, 5000er, priv. archive of Moeck Musikinstrumente + Verlag, Essen, 29 May 1967.

18 Comp. Witold Lutosławski. Correspondence with his Western Publishers and Managers 1966-1994, ed. Z. Skowron, vol. 1, Kraków 2019, pp. 29-33. 


\section{THE PUBLISHER MOECK AS FIRST DISTRIBUTOR OF THE PWM 'IN THE WEST'}

In fact, until then the Polish composers were mainly represented by the Cracow PWM, but also by the medium-sized West German publishing and instrument-making company of Hermann Alexander Moeck (1922-2010), located in the city of Celle. At the invitation of Józef Patkowski (1929-2005), whom Moeck had met at a musicological conference in Hamburg, and the Związek Kompozytorów Polskich (ZKP) [Polish Composers' Union] he traveled to Warsaw for the first time to meet some of the leading members there in the summer of 1958. During Moeck's one-week stay, and because the PWM wasn't well positioned for international trade in sheet music at that time, they discussed the possibilities of cooperation, beneficial to both parties ${ }^{19}$. In the context of measures being taken to decentralise Polish (music) cultural institutions after 1956, PWM was undergoing modernisation approximately until the early 1960s. This is why the leading personalities, such as the then director of the PWM, Tadeusz Ochlewski (1894-1975), were given more rights of self-determination, for example, to programme the production by himself and to allocate financial resources ${ }^{20}$. From then on the PWM also included contemporary works by the above-named authors in its catalogue, after the main editorial council (chaired by Lutosławski) was subdivided into the following programme councils: 'I. Rada d/s muzyki współczesnej [Council for contemporary music] [...] II. Rada d/s wyd. naukowych

19 S. Borchers, Wgląd do polsko-niemieckiej relacji $w$ muzyce wspótczesnej..., op. cit., p. 83.

${ }_{20}$ T. Ochlewski, [carbon copy of a] letter [to Prezydium Miejskiej Rady Narodowej/ Wydział Kultury, concerning the reduction of excessively centralized administration and the independent drawing up of own production plans at PWM], folder T084, Dyrektor Naczelny - Korespondencja, Rady Narodowe, Czasopisma, Polska Agencja Prasowa, Archiwum Państwowe w Krakowie, Ekspozytura w Spytkowicach, Kraków, the 26. November 1956; [Executive committees of the] Związek Kompozytorów Polskich, Stowarzyszenie Artystów Muzyków, Stowarzyszenie Artystów Lutników, [carbon copy of a] memorial [to J. Cyrankiewicz/ Prezes Rady Ministrów PRL, regarding planned measures to decentralise the cultural sector and the demand of the right to a say in this matter by the three organizations], folder 12-141, Memorialy skierowane do Premiera Cyrankiewicza w sprawie decentralizacji I/1A, archive of the ZKP, Polish Music Information Centre (POLMIC), Warszawa, 1 March 1957. i źródłowych [Council for academic and source publications] [...] III. Rada d/s wyd. pedagogicznych [Council for educational publications] [...] IV. Rada $\mathrm{d} / \mathrm{s}$ wyd. popularnych [Council for popular publications] $]^{21}$. Whatever the details, with the support of the ZKP Moeck got the permission from the MKiS to represent the PWM-catalogue in the Federal Republic of Germany ${ }^{22}$. Already in July 1958 he established the first 'provisional catalogue ${ }^{23}$ from a new series called Musica Polona Edition, only to offer a selection of performance materials produced by the PWM. A little later, he also added to it scores of music literature published by PWM prior to that date $^{24}$. Apart from works by Mieczysław Karłowicz (1876-1909), Stefan Kisielewski (1911-1991), Artur Malawski (1904-1957), Roman Palester (1907-1989), Stanisław Skrowaczewski (1923-2017), Michał Spisak (1914-1965) and Tadeusz Szeligowski (1896-1963) and many other composers, it also already included 'authors of the first hour' ${ }^{25}$ such as Bacewicz, Baird, Kilar, Kotoński, Lutosławski, Penderecki, Serocki and Szalonek.

Beside the rental of orchestra performance materials and the distribution of PWM printed scores, Moeck also had to manage the corresponding licences and rights of use, which he administered not only in West Germany, but throughout 'the West'. The handling of the copyright led to problems and even open conflicts very quickly. In 1946 this happened in connection with works by Karol Szymanowski

${ }^{21}$ N.N., schedule [named with the title: Rady Redakcyjne PWM], doc. no. 84, folder T171, Dyrektor Naczelny - Sekretariat, Rada Programowa (1952-61), Archiwum Państwowe w Krakowie [dalej AP], Ekspozytura [dalej E.] w Spytkowicach, without place, 16 April 1957.

${ }^{22}$ H. Höntsch, Polonia Edition im Hermann Moeck Verlag. Musiktransfer von Ost nach West. Anmerkungen eines Insiders, [in:] Sine musicae nulla vita. Festschrift Hermann Moeck zum 75. Geburtstag, ed. N. Delius, Celle 1997, p. 37.

${ }^{23}$ Ibidem, p. 38; ed. Hermann Moeck Verlag, Orchestermusik moderner polnischer Komponisten. Reversmaterialien, doc. no. 147, folder T051, Korespondencja 1956-1960, Archiwum Państwowe w Krakowie, Ekspozytura w Spytkowicach, without place and date [it is probably the first 'provisional catalogue' Höntsch wrote about, which was published in July 1958].

${ }^{24}$ Finds in the private archive of Moeck Musikinstrumente + Verlag: Musica Polona Edition. Eine Auswahl aus dem polnischen Musikschaffen bis zur Gegenwart und anderen Ausgaben des Polnischen Musikverlags, ed. Hermann Moeck Verlag, Celle 1959; Orchestermusik, ed. idem, Celle [November] 1959.

${ }^{25}$ H. Höntsch, Polonia Edition im Hermann Moeck Verlag..., op. cit., p. 39. 
(1882-1937) for the first time, and again in 1958. On that second occasion, the Vienna music publishing house of Universal Edition (UE) demanded the commitment of exclusive international rights of use and terms of protection until the year 1987, based on the common regulations of the Berne Convention of 1886 (and its further development up to 1908$)^{26}$ for Szymanowski's Stabat Mater and Symphony No. 3, which was performed then at the World Exhibition in Brussels by the Warsaw Philharmonic Orchestra conducted by Rowicki ${ }^{27}$. In those days the UE prohibited the Centrala Handlu Zagranicznego 'Ars Polona' (CHZ) [Foreign Trade Centre] the export of most of Szymanowski's works until further notice. Only in 1966 did the UE and PWM reach a contractual agreement concerning the first Polish complete edition of Szymanowski's works ${ }^{28}$.

\section{A FAILED POLISH EXPORT STRATEGY OF SUPPLYING MUSIC}

In the context of Poland's outward (cultural) opening and the restructuring measures of the planned economy after 1956, commissioned by the Ministerstwo Handlu Zagranicznego (MHZ) [Ministry of Foreign Trade] as well as the Ministerstwo Kultury i Sztuki [Ministry for the Arts and Culture], Ars Polona became Poland's sole exporter and importer of records,

\footnotetext{
26 International Copyright Union. Bern Convention 1886, Paris Convention 1896, Berlin Convention 1908, Library of Congress (ed.), [in:] Copyright Bulletin, no. 13, Washington 1908, p. 19-24.

27 Universal Edition A.G., [duplicate of a] letter [to CHZ Ars Polona'], document no. 279, folder T224, Dyrektor Naczelny - Redakcje, Korespondencje (1954, 1957-58) Centrala Handlu Zagranicznego 'Ars Polona', Archiwum Państwowe w Krakowie, Ekspozytura w Spytkowicach, Vienna, 9 June 1958; idem, [duplicate of a] facture [no. 19388 to CHZ AP], doc. no. 281, T224, Archiwum Państwowe w Krakowie, Ekspozytura w Spytkowicach, Vienna, 9 June 1958; idem, [duplicate of a] letter [to CHZ AP], doc. no. 283, T224, Archiwum Państwowe w Krakowie, Ekspozytura w Spytkowicach, Vienna, 2 July 1958; H. Moeck, [duplicate of a] letter [to CHZ AP, with the subject Szymanowski, Paderewski, Panufnik], doc. no. 285, T224, Archiwum Państwowe w Krakowie, Ekspozytura w Spytkowicach, Celle, 2 July 1958.

${ }_{28}$ B. Gierlicki/ CHZ Ars Polona, [carbon copy of a] letter [to O. v. Spitzmüller, Universal Edition A. G.], doc. no. 75, folder T107 Korespondencja, Instytucje i Urzędy 'A-M' (1964-67), Archiwum Państwowe w Krakowie, Ekspozytura w Spytkowicach, Vienna, 25 May 1966.
}

sheet music and books ${ }^{29}$. However, like the Universal Edition, Moeck was also not allowed to communicate directly with its business partner PWM, but only indirectly via the CHZ 'Ars Polona'. This resulted in time-consuming negotiations, a costly mutual delivery of scores, performance materials, transparency templates and records and, of course, annoyance and misunderstandings on both sides. For example, from time to time some orchestral parts reached the German concert organizers only just in time or even too late. With regard to the Musica Polona Edition Baird once wrote to Moeck:

You'll get the performance material through Ars Polona. But, because it is no secret, not only in Poland, that Ars Polona works as badly as possible, in this case you should order the orchestra and choir material prematurely (i. e. - as early as possible $)^{30}$.

In 1962 the then general director of Ars Polona, Teodor Brachmański (biogr. data unknown), emphasized a new initiative of cooperation with record companies such as Columbia, EMI and Philips in a statement About the export of records in the music magazine "Ruch Muzyczny" 31 , also documented in the music-record magazine "Billboard" 32 . However, the verdict from the ZKP was scathing. In 1963, during its General Meeting Zygmunt Mycielski (1907-1987) criticized, for example:

Ars Polona's promotion and delivery of materials and releases of Polish contemporary music abroad also fails. This could probably only be changed by the takeover of its function by the PWM - which is highly unlikely to take place in

29 R. Waschko, Polish Company Sets Disk Trade Deal with Columbia, "Billboard. The International Music-Record Newsweekly" 69, 23 November 1963, p. 32.

30 T. Baird, letter [to H. Moeck], loose, without folder, priv. archive of Moeck, Warsaw, 3 May 1961. German orig. text: 'D[as] Aufführungsmaterial bekommen Sie durch Ars Polona. Weil es aber nicht nur in Polen kein Geheimnis ist, dass Ars Polona so schlecht wie nur möglich arbeitet, müssten Sie in diesem Fall das Orchester und Chormaterial vorzeitig (das heisst - so früh wie möglich) fordern'.

${ }_{31}$ T. Brachmański, O eksporcie płyt gramofonowych, "Ruch Muzyczny” 1962 no 15, p. 4.

32 Comp. R. Waschko, Brachmanski to West for Talks, in: "Billboard" 69, 23 November 1963, p. 37; idem, Polish Company Sets Disk Trade..., op. cit., p. 32; N.N., EMI, Philips Deal Disks with Poland, "Billboard" 70, 18 January 1964, p. 20; N.N., Higher Each Year. Export of Polish Disks Make Gain, "Billboard” 70, 11July 1964, p. 6. 
the current state of affairs. The commercial attitude of both, Polskie Nagrania and Ars Polona, has nothing to do with any promotion of our contemporary art, both in this country and $\operatorname{abroad}^{33}$.

In fact, Mycielski's requirement was fulfilled in 1971, when PWM took the matters previously handled by Ars Polona in its own hands, establishing its Warsaw Biuro Handlu Zagranicznego [Foreign Trade

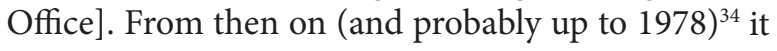
also handled all matters of the Musica Polona Edition. In a subsequent article about the Problems of Polish music export, the music journalist Zofia Jaźwińska (biogr. data unknown) also emphasized, for example:

That no one needs to be persuaded that the export of Polish musical culture - in all its manifestations - is a matter of great importance. [...] That we have many outstanding soloists, conductors, ensembles already known in the world, many winners of international competitions. [...] That our music and our musicians, our competitions and festivals are becoming increasingly of general interest ${ }^{35}$.

But the 'failed' music export wasn't the only debate. Rather, the (international) handling of authors and publishing rights also became an issue at that time again: Ars Polona and Moeck, for example, increasingly disagreed about the mutual accounting of material rental fees and royalty payments. This is why the Stowarzyszenie Autorów 'ZAiKS' [Author's

33 Z. Mycielski, Walne Zgromadzenie Związku Kompozytorów Polskich, "Ruch Muzyczny" 1963 no 5, p. 2. Polish orig. text: 'Propaganda i dostarczanie za granicę materiałów i wydawnictw polskiej muzyki współczesnej przez Ars Polona również nie zdaje egzaminu. Mogłoby się to zmienić chyba jedynie przez przejęcie tej funkcji przez PWM - co w obecnym stanie rzeczy jest dalekie od możliwej realizacji. Handlowe nastawienie zarówno Polskich Nagrań jak i Ars Polona nie ma nic wspólnego z jakąkolwiek propagandą naszej współczesnej sztuki zarówno w kraju jak i za granicą.

34 The last information about new releases by the PWM is to be found in the following publisher's bulletin: Aus dem Polnischen Musikverlag Krakau. Neuerscheinungen, ed. Moeck Verlag und Musikinstrumentenwerk, “Moeck Information”, September/1978, pp. 1-2.

35 Z. Jaźwińska, Problemy eksportu muzyki polskiej, "Ruch Muzyczny” 1963 no 5, p. 20. Polish orig. text: „Że nikogo chyba nie trzeba przekonywać, iż eksport polskiej kultury muzycznej — we wszystkich jej przejawach - jest sprawą ogromnej wagi. [...] Że mamy wielu wybitnych solistów, dyrygentów, zespołów znanych już w świecie, wielu laureatów międzynarodowych konkursów. [...] Że nasza muzyka i nasi muzycy, nasze konkursy i festiwale budzą za granicą coraz bardziej powszechne zainteresowanie".
Association] was also involved in this conflict. The ZAiKS already cooperated with the Western Author's Societies such as the West German Gesellschaft für musikalische Aufführungs- und mechanische Vervielfältigungsrechte (GEMA) [Society for musical performing and mechanical reproduction rights], the French SACEM or the US-American SESAC on the basis of the (more or less loosely handled) international cross-border settlement ${ }^{36}$. However, the biggest problem was that consistent regulations across the mutual borders of the East-West conflict, and a foreign exchange market between the West German market and Poland's planned economy, apparently didn't exist $^{37}$. Although Moeck officially got an account at 'ZAiKS' in $1962^{38}$, he couldn't transfer his income to Germany. Once Moeck 'remember[ed] that the account had grown quite a bit ${ }^{39}$, he asked himself what to do with all the Polish złotys. According to this anecdote, Serocki replied: 'You know what, Hermann, I'll go to a Russian officers' mess and we'll buy caviar! ${ }^{30}$. The same applied to the composers from Poland who had their own accounts within the publishing house of Moeck. They used the money, for example, to cover their costs of travel in Western countries, or to buy Western products. Lutosławski and Penderecki, for example, bought good quality tracing paper and Indian ink to draw ${ }^{41}$. The latter, as well as

${ }^{36}$ H. Höntsch, [carbon copy of a] letter [to K. Penderecki], folder Briefwechsel Penderecki, 5000er, priv. archive of Moeck, without place, 28 September 1961.

${ }^{37}$ H. Höntsch, Polonia Edition im Hermann Moeck Verlag..., op. cit., p. 41.

${ }^{38} \mathrm{~K}$. Serocki, letter [to H. Moeck, concerning the opening of a ZAiKS-account for the income from the rental of performance materials in Poland], folder Serocki, 5000er, priv. archive of Moeck Musikinstrumente + Verlag, Warszawa, 28 June 1962; H. Moeck, [carbon copy of a] letter [to K. Serocki], folder Serocki, priv. archive of Moeck, without place, 3 July 1962.

39 S. Borchers, A Conversation with Hermann Moeck and Herbert Höntsch [unpublished sound recording], Celle 2009.

40 Ibidem.

${ }^{41}$ W. Lutosławski, letter [to H. Moeck, concerning the request to send black drawing ink], folder Lutosławski, Marco, 5000er, priv. archive of Moeck, Warsaw, 14 January 1961; H. Moeck, [carbon copy of a] letter [to W. Lutosławski, concerning an order of black drawing ink], folder Lutosławski, priv. archive of Moeck, without place, 23 January 1961; H. Moeck, [carbon copy of a] letter [to K. Penderecki], folder Briefwechsel Penderecki, 5000er, priv. archive of Moeck, without place, 16 May 1961; L. Schlömer, Licht und Fotopauserei, Technische Papiere, delivery note [concerning tracing paper in A4 format], folder Lutosławski, priv. archive of Moeck, Hannover, 1 August 1962; H. Höntsch, [carbon copy of a] letter 
Serocki, also purchased cars, made by Volkswagen, Mercedes-Benz and Opel ${ }^{42}$. Penderecki could finance his Mercedes-Benz after the first success of his St. Luke Passion in 1966, when he received the Großer Kunstpreis des Landes NRW [the large Art Prize of North Rhine-Westphalia] ${ }^{43}$. In 1971, for example, he was checked out by the Służba Bezpieczeństwa [State Security Service] in Cracow, because his Mercedes was wrongly parked ${ }^{44}$. And Kotoński bought an UHER tape recorder after teaching at the Stockholm Music Academy in Sweden, which in 1968 he also used at the Warsaw Państwowa Wyższa Szkoła Muzyczna [State Higher School of Music], today's Chopin University of Music ${ }^{45}$.

[to W. Lutosławski] folder Lutosławski, priv. archive of Moeck, without place, 4 November 1963; H. Höntsch, [carbon copy of a] letter [to K. Penderecki] folder Penderecki, priv. archive of Moeck, without place, 22 April 1966.

${ }^{42}$ K. Serocki, order form [to Volkswagen-Händler Otto Martin, concerning the car purchase of a VW Export], folder Serocki, 5000er, priv. archive of Moeck, Celle, 7 August 1961; K. Penderecki, confirmation of order [to Volkswagen-Vertretung Otto Martin, concerning the car purchase of a VW Export Limousine, Typ 113], folder Briefwechsel Penderecki, 5000er, priv. archive of Moeck, Celle, 6 December 1961; Wedemeyer, [carbon copy of a] letter [to Adam Opel AG, Export Abteilung/ Direktverkäufe, concerning the car purchase of a Opel Record Coupé], folder Serocki, priv. archive of Moeck, Altencelle, 30 April 1965; H. Moeck, [carbon copy of a] letter [to Adam Opel AG], folder Serocki, priv. archive of Moeck, without place, 11 May 1965; H. Höntsch, [carbon copy of a] letter [to K. Penderecki, concerning the shipping of car spare parts for a Mercedes Typ 190 B], folder Penderecki, priv. archive of Moeck, without place, 11 June 1965; K. Serocki, [carbon copy of a] letter [to Daimler-Benz Aktiengesellschaft, Exportabteilung, concerning the collection of a Mercedes Typ 200 in Stuttgart], folder Serocki, priv. archive of Moeck, without place, 27 April 1968; Daimler-Benz AG, [copy of a] confirmation of order [to K. Serocki, concerning the car purchase of a Mercedes Typ 230/4], folder Serocki, priv. archive of Moeck, Stuttgart, 2 January 1974.

${ }^{43}$ Deutsche Presse-Agentur GmbH, Kunstpreis des Landes NRW. $Z u$ den Ausgezeichneten gehören zwei Ausländer, in: "Kölner Stadtanzeiger", 21 July 1966.

${ }_{44}$ T. Gawron, memo [to Wydział Ruchu Drogowego KMMO w Krakowie], dokument nr 67/72, IPN Kr 009/8692 (39997/1), Instytut Pamięci Narodowej, OBU i AD w Warszawie, Kraków, 2 February 1971; Kpt. B. Ptak, Naczelnik Wydziału Ruchu Drogowego KMMO w Krakowie, letter [to Służba Bezpieczeństwa, Komendy Wojewódzkiej MO w Krakowie], dokument nr 66/72, IPN Kr 009/8692 (39997/1), IPN, OBU i AD w Warszawie, Kraków, 3 February 1971; M. Hakerko, memo, dokument nr 69/72, IPN Kr 009/8692 (39997/1), IPN, OBU i AD w Warszawie, Kraków, 8 February 1971.

${ }^{45}$ W. Kotoński, letter [to O. Tomek], music archive no. 149 Otto Tomek, Akademie der Künste Berlin, Warsaw, 14 November 1968; W. Kotoński, letter [to O. T.] music archive no. 149, A. d. K. Berlin, Warsaw, 14 January 1969; W. Kotoński, letter [to O. Tomek] music archive no. 149, A. d. K. Berlin, Warsaw, 2 March 1969.

\section{ACROSS THE EAST-WEST BORDER OR THE DILEMMA WITH THE COPYRIGHT}

To simplify the processes on both sides, Moeck and the composers searched for opportunities to bypass the communication and shipping via Ars Polona. Unquestionably looking for exclusiveness for the Western market of contemporary music, and encouraged by the composers, Moeck decided to publish the (at that time) latest Polish works directly by his own Edition Moeck, the so called 5000-series. Ochlewski even helped Moeck to get the transparency templates of Penderecki's Psalms of David for mixed choir, string instruments and percussion (1958) and Emanations for two string orchestras (1958-59) awarded in $1959^{46}$. The Psalms of David, first published by PWM as PWM Edition no. 491 (@ 1959) and then also edited as Edition Moeck no. 5002 (๑1960), and the Emanations (E. M. 5004/ (1960), which later were also published in a co-production as PWM no. 6894 (@1970), were among the first pieces in the new catalogue of Polish contemporary music at Moeck. Especially the international breakthrough of the young Penderecki after the first (more or less) 'scandalous' performance of Anaklasis for string orchestra and 6 groups of percussion (1959-60) in Donaueschingen, but also his Threnody 'To the Victims of Hiroshima' for 52 string instruments (1959-61), created growing tensions between Moeck, Ars Polona and the ZAiKS. Unlike Threnody, published as PWM 4523 (ㄷ1961) only after its first performance at the $5^{\text {th }}$ Warsaw $\mathrm{Au}$ tumn, Anaklasis was first published only in Celle as E. M. 5003 (๑1960) and even later also in Cracow as PWM no. 6691 (@1968). On the Polish side it wasn't welcome that the Edition Moeck included the exclusive world rights, so that Poland had to pay foreign currency for performance and publication licences of works by their own countrymen. Even the visit of Brachmański in Celle couldn't change this in $1962^{47}$.

${ }^{46} \mathrm{H}$. Moeck, [carbon copy of a] letter [to K. Penderecki, concerning the negotiations with PWM for the publication of Psalms of David and Emanations], folder Briefwechsel Penderecki, 5000er, priv. archive of Moeck, without place, 21 April 1960.

${ }^{47} \mathrm{H}$. Höntsch, [carbon copy of a] letter [to K. Penderecki with a comment about the visit of T. Brachmański at Moeck in April '62], folder Briefwechsel Penderecki, 5000er, priv. archive of Moeck, without place, 10 August 1962. 
Moeck's publishing director Herbert Höntsch (19172013) once described the situation as follows:

So it became increasingly difficult for Polish authors to give their works abroad; from 1963 onwards, they referred to it several times in letters. And in a personal conversation our business partners explained to us that they really hadn't imagined the representation of their catalogue in this way ${ }^{48}$.

In May 1962 Penderecki warned Moeck the first time:

I think we're gonna have trouble with Ars Polona. Brachmański is acting in a bold and foolish manner. - Please clarify your relationship with the ZAiKS. My contracts with you have been requested once again. But I refused $i^{49}$.

When the fronts hardened, Serocki subsequently also offered his help in the matter:

How do you intend to act - depending on the situation and which solution is acceptable to you? [...] Do you think the time is ripe for an intervention by the Composers' Union [...] or do you think [...] we should wait? [...] May I exploit the correspondence $[\ldots]$ publicly $[\ldots]$ in the event of an intervention? ${ }^{50}$

After the charging of rental material of Lutosławski's Muzyka żałobna [Funeral music] for string orchestra (1954-58), which he had given to Moeck for its transmission to a Radio Television Françoise concert in Strasbourg before, Ars Polona alleged a breach of contract and demanded the corresponding payment of rental fees. However, Moeck rejected this, too, because it was the private material by the composer ${ }^{51}$. Thereupon, during the $6^{\text {th }}$ Warsaw Autumn in the same year, Ars Polona tried to prevent an exhibition of the

${ }^{48}$ H. Höntsch, Polonia Edition im Hermann Moeck Verlag..., op. cit., p. 41. German orig. text: 'Es wurde für die polnischen Autoren also zunehmend schwieriger, ihre Werke ins Ausland zu geben; ab 1963 wiesen sie in Briefen mehrfach darauf hin. Und im persönlichen Gespräch erklärten uns unsere Geschäftspartner, daß sie sich so die Vertretung ihres Katalogs eigentlich nicht gedacht hätten'.

${ }^{49}$ H. Moeck, [carbon copy of a] letter [to K. Penderecki], folder Briefwechsel Penderecki, 5000er, priv. archive of Moeck, without place, 14 May 1962.

${ }^{50}$ K. Serocki, letter [to H. Moeck], folder Serocki, 5000er, priv. archive of Moeck, Warszawa, 30 May 1962.

${ }^{51}$ H. Moeck, [carbon copy of a] letter [to W. Lutosławski], folder Lutosławski, priv. archive of Moeck, without place, 22 June 1962.
Moeck printed scores at the PWM exhibition stand in the foyer of the Filharmonia Narodowa: This concerned the scores from Anaclasis, Emanations, Psalms of David, Wymiary czasu i ciszy [Dimensions of Time and Silence] for 40-part mixed choir, percussion and strings (1959-60 - E. M. 5005/ @1961 and PWM 6951/ (01970) by Penderecki, the Canto per complesso da camera (1961 - E. M. 5014/ (1962 and PWM 7038/ (1)1970) by Kotoński and the Jeux vénitiens for chamber orchestra (1961 - E. M. 5012/ ( 1962 and PWM 6784/ (C)1970) by Lutosławski ${ }^{52}$. Afterwards Kotoński mentioned: '[T] he notes had been issued, but Ars Polona's representative prohibited their sale. However, some copies were sold under the table ${ }^{53}$. At this time the conflict was already escalating on the Polish side and Moeck was reduced to a mere spectator at the outer edge. This happened also because the ZKP now tried to actively influence the decision-making processes in the PWM, the ZAiKS and the MKiS. However, initially this seemed to be without success and the situation escalated in 1963, when Ars Polona finally obtained the decision that the authors should no longer publish their works with Moeck or any other Western music publishing house. At this moment Penderecki, for example, wrote to Moeck again: 'What Kotoński writes is unfortunately true. Ars Polona, the ZAiKS et consortes make all publishing abroad impossible ${ }^{54}$.

\section{A BAN TO PUBLISH WITH WESTERN MUSIC PUBLISHERS. THE DIVISION OF THE WORLD}

Probably with a certain lead time, but almost two years later, in October 1965, the process began to move again, when the executive committee of the

${ }^{52}$ H. Höntsch, letter [to W. Kotoński, on organizational questions concerning the exhibition of scores at the WJ '62], folder Briefwechsel Kotoński, 5000er, priv. archive of Moeck, without place, $8 \mathrm{Au}$ gust 1962.

${ }_{53}$ W. Kotoński, letter [to H. Höntsch], folder Kotoński, priv. archive of Moeck, Warszawa, 24 September 1962. German orig. text: 'Die Noten waren [...] ausgestellt [...] [worden], der Vertreter von Ars Polona hat jedoch [...] deren Verkauf verboten. Es wurden jedoch einige Exemplare unter dem Tisch verkauft'.

${ }^{54}$ K. Penderecki, letter [to H. Moeck], folder Briefwechsel Penderecki, 5000er, priv. archive of Moeck, Kraków, 18 April 1963. German orig. text: 'Das was Kotoński schreibt ist leider wahr. Ars Polona, ZAiKS et consortes machen alles [...] Verlegen im Ausland unmöglich'. 
ZKP addressed a memorandum to the then Minister for the arts and culture, Lucjan Motyka (1915-2006), and Director of the Zespół do Spraw Muzyki [Music Department], Wiktor Weinbaum (1915-1999). With reference to the Ustawa o prawie autorskim [Copyright Act] of 1952 the ZKP noted here 'an observation concerning the dissemination of Polish music in Poland and abroad ${ }^{35}$ in relation to the delivery of sheet music by distribution companies, publishers, performing and music institutions. In another letter to the Minister the ZKP also formulated its support for the proposal 'that in all contracts with foreign publishers a reservation is included that the composer or PWM, as a sub-publisher, will have their own orchestral material with the right to use it in Poland and the socialist countries ${ }^{56}$. And, in January 1966, Lutosławski even wrote a personal letter addressed to Motyka describing his situation as composer and pointing out that foreign-currency based cooperation with Western music publishers such as 'Schott / FRG/, Universal Edition /Austria/, Chester /England/ and C. F. Peters $/ U S A /{ }^{57}$ is essential for his international advancement or, rather, the worldwide reputation of the contemporary Polish music culture. Only a few months later he started his correspondence

55 A. Dobrowolski/ Sekretarz Generalny and S. Śledziński/ Prezes, [carbon copy of a] letter [to L. Motyka/ MKiS], doc. no. 4075/65, folder 12-87, Sprawy wydawnicze polskich utworów za granicą (1953-74), archive of the ZKP, POLMIC, Warszawa, 30 October 1965. Polish orig. text: '[...] spostrzeżenie dotyczące rozpowszechniania muzyki polskiej w kraju i za granicą [...]'; comp. B. Bierut/ Prezydent Rzeczypospolitej and J. Cyrankiewicz/ Prezes Rady Ministrów, 234 Ustawa z dnia 10 lipca 1952 r. o prawie autorskim, [in:] Dziennik Ustaw Polskiej Rzeczypospolitej Ludowej no. 34, Warsaw, 31 July 1952, p. 273-278, http://monitorpolski.gov.pl/du/1952/s/34/234/D1952034023401.pdf.

${ }^{56}$ G. Bacewicz/ Wiceprezes and W. Kotoński/ Wiceprezes, [carbon copy of a] letter [to L. Motyka/ MKiS, concerning the possibilities of publishing Polish works abroad], doc. no. 4237/65, folder no. 12-87, Sprawy wydawnicze polskich utworów za granica (1953-74), archive of the Związek Kompozytorów Polskich, Polish Music Information Centre, Warszawa, 3 November 1965. Polish orig. text: 'Zarząd Główny Związku Kompozytorów Polskich popiera to w całej rozciągłości, aby we wszelkich umowach z wydawcami zagranicznymi umieszczane było zastrzeżenie, że kompozytor lub P. W. M., jako podwydawca, dysponować będą własnym materiałem orkiestrowym z prawem wykorzystywania go na terenie Polski i Krajów Socjalistycznych'.

${ }_{57}$ W. Lutosławski, [duplicate of a] letter [to L. Motyka, MKiS], document no. 287, folder T197, Redaktor Naczelny - Redakcje, Korespondencje, Ministerstwo Kultury i Sztuki - Departament Ekonomiczny (1963-1966), Archiwum Państwowe w Krakowie, Ekspozytura w Spytkowicach, Warszawa, 24 January 1966. with Hansen, when Moeck also specified new details of further co-productions with Ars Polona, PWM and the ZAiKS ${ }^{58}$. But the difference now was that the Polish side extended their strategic considerations also to other already interested Western music houses such as Universal Edition, Schott and even Hansen. Because of this Moeck lost its status as the only 'Western representative' of the PWM, in fact, in 1966. This also was the moment when Moeck's leading author Penderecki switched to its bigger and internationally better placed competitor Schott. In the end an agreement was reached that divided the copyright into an 'Eastern' and a 'Western' sphere of influence. Since then it has been printed in the scores, as follows:

C 1967 by Moeck Verlag, Celle/FRG for all countries with the exception of:

Copyright 1967 by Polskie Wydawnictwo Muzyczne, Krakow, Poland, for Poland, Albania, Bulgaria, Czechoslovakia, German Democratic Republic, Hungary, Rumania, Union of Soviet Socialist Republic, Chinese Peopless Republic, Cuba, North Corea, North Viet-Nam ${ }^{59}$.

as well as in sub-editions:

Copyright 1967 by PWP, Przedstawicielstwo Wydawnictw Polskich, Warszawa, Poland.

All rights in the Unites States, Canada and Mexico represented by SESAC, New York, U. S. A. ${ }^{60}$

${ }^{58}$ H. Höntsch, [carbon copy of a] letter [to W. Kotoński, c/o WDR, Studio f. elektronische Musik, concerning two meetings in Celle and Warsaw with M. Tomaszewski/ PWM director], folder Briefwechsel Kotoński, 5000er, priv. archive of Moeck, without place, 15 November 1966; H. Höntsch, [carbon copy of a] letter [to W. Kotoński, concerning co-productions with PWM and the permission of all Polish composers to publish their works abroad], folder Kotoński, priv. archive of Moeck, without place, 9 January 1967; W. Kotoński, letter [to $\mathrm{H}$. Höntsch, regarding Tomaszewski's agreement to the Moeck-PWM co-production of the work A battere], Köln, 17 January 1967.

${ }_{59}$ K. Penderecki, Passio et mors Domini Nostri Iesu Christi Secundum Lucam (1965), Celle and Kraków 1967, p. 7; comp. S. Borchers, Wglad do polsko-niemieckiej relacji w muzyce wspótczesnej..., op. cit., p. 84 .

${ }^{60}$ W. Kotoński, Concerto per quattro for harp, harpsichord, guitar, piano and chamber orchestra (1965), ed. E. Widłak, Kraków 1966, p. 5 [sub-published by Moeck, Celle 1966]. 


\section{CONTEMPORARY POLISH POETRY IN CONTEMPORARY POLISH VOCAL CYCLES - AN OFFER FOR THE WESTERN MUSICAL LIFE AND ITS MUSIC MARKET}

The first publishing number of the Edition Moeck was no. 5001/ ( 1960 assigned to Szalonek's triptych Confessions for narrator, mixed choir and chamber orchestra (1959) to words by Kazimiera Iłłakowiczówna (1892-1983), where the composer advanced his individual approach to dodecaphonic techniques. Because Moeck had 'no objection if you keep the distribution rights for Poland to yourself, but I would appreciate it if I could have [... ] [it] for the whole world' ${ }^{\prime}$, Szalonek confirmed that he '[r] egarding the Confessions [had] not concluded any contract with the Polish Music Publisher'62. For its premiere at the Warsaw Autumn in 1959 PWM had already produced the orchestra material for the $1^{\text {st }}$ and $3^{\text {rd }}$ parts. And now, while Szalonek was finishing the entire work for its premiere at the Summer Courses in Darmstadt in 1960 , Moeck prepared the material of the $2^{\text {nd }}$ part. Because Wolfgang Steinecke (1910-1961) ${ }^{63}$, who initiated the Summer Courses in 1946, thought out loud about a performance in German at this time, Szalonek then endeavored to provide an appropriate translation from the Polish original and enlisted the writer and translator Witold Wirpsza (1918-1985), 'who does these things for the Polish Music Publisher' ${ }^{\prime}$ generally. Wirpsza also translated the German text underlay for the PWM piano reduction

${ }_{61}$ H. Moeck, [carbon copy of a] letter [to W. Szalonek], folder Shinohara, Sikorski, Soler, Szalonek, Szathmáry, Szymanski, Weiß, 5000 er, priv. archive of Moeck, without place, 8 March 1960. German orig. text: 'Ich habe [...] nichts dagegen, wenn Sie die Verleihrechte für Polen behalten, mir wäre es [jedoch] schon lieb, wenn ich [...] dieses [...] für die ganze Welt haben könnte'

62 W. Szalonek, letter [to H. Moeck], folder Szalonek, priv. archive of Moeck, Katowice, 22 March 1960. German orig. text: 'Hinsichtlich der "Geständnisse" habe ich keine Verträge mit dem Polnischen Musikverlag geschlossen'.

63 W. Steinecke, [carbon copy of a] letter [to W. Szalonek], archive of the Internationales Musikinstitut Darmstadt, without place, 19 January 1960.

${ }^{64}$ W. Szalonek, letter [to W. Steinecke], archive of the Internationales Musikinstitut Darmstadt, Katowice, 20 March 1960. German orig. text: 'Ich habe [eine] Übersetzung[en] bei[m] Herrn Wirpsza [machen lassen], der diese Sachen für den polnischen Musikverlag macht'. (no. 3388/ @1 1959 and no. 3548/ ( 1959) of Serocki’s two vocal cycles Eyes of Air for soprano and piano (1957) to poetry by Julian Przyboś (1901-1970) and Heart of the Night for baritone and piano (1956) to poems by Konstanty Ildefons Gałczyński (1905-1953). In addition to that, Moeck also planned to publish the orchestral versions as part of his new Edition Moeck at the same time. But, because of linguistic deficiencies, the publisher decided to revise the existing translation by Wirpsza (see Fig. 3f) ${ }^{65}$. Altogether, this project was accompanied by numerous difficulties which triggered a costly and prolonged correction process. All parties underestimated the complex relationship between the accents of the Polish poetic texts and the composed rhythmic-melodic progression in the music, which had to be transmitted anew into the German and English words and text modules.

Eyes of Air, as well as Heart of the Night, '[b]oth works are written in free twelve-tone ${ }^{36}$ and mark the moment when Serocki was also experimenting with dodecaphonic means, sparing and sensitive forming of the tonal and harmonic ground, resulting in a timbral interweaving of musical and poetic expression. Starting from a 12-tone row, he enhanced it in the further process by serial permutation techniques (inversion, retrogradation, retrograde inversion etc.). $\mathrm{He}$ transferred it into various patterns, which are distributed with varying intensity through all tonal registers ${ }^{67}$. In the vocal part as well as in the instrumental accompaniment Serocki was working with crossings and mutual interpenetrations of separate running row pattern.

Even if he didn't use these principles as a mere structural approach only to get an external effect, as can be found in works belonging to the so called 'Darmstadt School' from the same period, he ordered the rhythmic-metrical level in both cycles under the rational aspects of serialism and punctualism. Various studies have shown that Serocki's dramaturgical concept in Eyes of Air, for example, is based on the

${ }^{65}$ H. Höntsch, [carbon copy of a] letter [to K. Dedecius], folder Dedecius, priv. archive of Moeck, without place, 31 August 1961.

${ }^{66} \mathrm{~K}$. Serocki, letter [to O. Tomek, offering the two orchestral versions of Heart of the Night and Eyes of Air], music archive 149, Otto Tomek, Akademie der Künste Berlin, Warszawa, 29 November 1963. German orig. text: 'Beide Werke sind im freien Zwölftonsatz geschrieben'.

${ }^{67}$ I. Lindstedt, Dodekafonia i serializm w twórczości kompozytorów polskich XX wieku, Lublin 2001, p. 164. 
content selection, the arrangement and the restructuring of the lyric ground. The poems Spotkanie [Eng. Meeting/ Ger. Das Treffen], Bez [Lilac/ Der Flieder], Chwila [A Passing Moment/ Augenblick], Ścieżka [The Path/ Der Pfad] and Wieczór [Evening/ Der Abend], were chosen according to their formal and rhythmic aspects. To bring the vocal part into line with the consonants, vowels, the ups and downs of the Polish lyric and the irregular verse structure of the poems, the musical metre constantly changes from measure to measure. The cycle begins with the Meeting, kept plain, a poetic apostrophe to the beloved alluding to fear of death. The singing voice goes through small intervals. The further dramaturgical sequence follows in Lilac and A Passing Moment with moods contrasted in birth, blossoming, life, delight and death, transience, grief and gloom. Based on key words and poetic phrases Serocki here contrasts tonal and rhythmic material, but merges the vocal and instrumental concurrently by increasingly using quarter-triplets while creating an atmosphere of illusion. The Path represents the dramaturgical climax and describes the moment of separation of two people. The lyrical expression changes constantly between moods of melancholy, determination and delight, while the music reacts more and more to the lyrical content. Finally, in the Evening, the mood is full of nostalgia and thoughtful reminiscence of the previous separation. As a result, the canto is merged completely with the instrumental part, while directly underlining the key words together, varying each time on the base of smaller and smaller rhythmic values ${ }^{68}$.

\section{THE TRANSLATION PROJECT - CULTURAL TRANSFER ON ITS BORDER}

Because of the difficulties that arose in the translation of the poems in Eyes of Air, Höntsch turned with a request for help to the renowned writer and

${ }^{68}$ K. Dąbek, Cykl pieśni "Oczy powietrza” Kazimierza Serockiego. Próba interpretacji, online: <http://meakultura.pl/publikacje/ cykl-piesni-oczy-powietrza-kazimierza-serockiego-proba-interpretacii-1388> (publication date: 27 November 2015; date of access: 3.07.2020); I. Lindstedt (see fn. no 67), pp. 163-169, p. 184.; S. Będkowski, Serie dźwiękowe w twórczości Kazimierza Serockiego, "Muzyka” 1996 no 1, pp. 3-39; idem, Zmienne metra w twórczości Kazimierza Serockiego, "Muzyka" 1996 no 4, pp. 15-25. translator of Polish and Russian literature Karl Dedecius (1921-1916). In 1980 he was commissioned to found the Deutsches Polen-Institut [German Poland-Institute] in Darmstadt by the then Federal Government. And, as it happened, in the early 1960s, he had already prepared a publication with the translated lyrics by Przybos (see Fig. 3a) ${ }^{69}$. For this reason, he agreed:

Basically, you are right that $[\ldots]$ the texts should be revised - this especially, because these are the lyrics of such an idiosyncratic and subtle poet as Przyboś. I've already translated some of Przybośs poems [...] Unfortunately there is only one poem that is included in the song cycle - namely Evening ${ }^{70}$.

When Serocki was informed of the revision by Dedecius, he drew 'attention to the following points':

1/ Wirpsza is the German translator of the text/ licensed by Przyboś/ registered officially at ZAiKS. Therefore, it should be given a permission by Wirpsza and Przyboś, [...] a rather 'delicate' matter [...].

2/ The translation of Wirpsza corresponds exactly to the melodic progression, especially with regard to the prosody / accents/, I hope that Mr. Dedecius would act as exactly in that regard; I would like to reserve the right [...] to compare the new translation with the melodic progression. A sung word isn't the same as a read word, here - in my opinion - [...] the absolute correspondence of the word with the melodic line [is more important] than the keeping of the poetic sense, which can anyway be viewed differently by each person ${ }^{71}$.

${ }^{69}$ J. Przyboś, Gedichte, translated by K. Dedecius, Ebenhausen bei München 1963 .

${ }^{70}$ K. Dedecius, letter [to H. Moeck], folder Dedecius, priv. archive of Moeck, Frankfurt am Main, 16 October 1961. German orig. text: 'Grundsätzlich haben Sie recht, daß man [...] die Texte revidieren müßte - vor allem, da es sich um die Texte eines so eigenwilligen und subtilen Dichters wie Przyboś handelt. Ein paar Gedichte von Przyboś habe ich bereits übersetzt [...] Leider kommt da nur ein Gedicht vor, das im Liederzyklus enthalten ist - nämlich DER ABEND'.

71 K. Serocki, letter [to H. Höntsch], folder Serocki, 5000er, priv. archive of Moeck, Warszawa, 21 September 1961. German orig. text: '1/ der bei ZAIKS offiziell eingetragener deutscher Übersetzer des Textes/ mit Lizenz von Przyboś/ ist Wirpsza. Es müsste also von Wirpsza und von Przyboś die Zustimmung erteilt werden, [...] eine ziemlich "delikate" Angelegenheit [...]. 2/ die Übersetzung von Wirpsza stimmt genau überein mit dem melodischen Verlauf, insbesondere was die Prosodie /Akzente/ anbetrifft, ich hoffe, dass Herr Dedecius in dieser Hinsicht ebenso genau handeln würde und ich möchte mir Vorbehalten [...] die neue Übersetzung mit dem melodischen Verlauf zu vergleichen. Ein gesungenes Wort ist ja nicht ein gelesenes Wort, hier 
Although Wirpsza, as Przyboś writes, did the translation without asking the poet ${ }^{72}$, the poet agreed with the new translation by Dedecius ${ }^{73}$. So, the first point was easily clarified. But the second point was not that simple to clarify, because Serocki's opinion was opposed to the translator's opinion, which was in favor of poetic content. To the first proposal of a verse line in Evening by Dedecius (see Fig. 3b and 3c) Höntsch, for example responded that the translated

text, in its present form, can't be placed below the melody given by Serocki just like that. It could be fixed easily, if you would agree to the change of a few words only. [...]

2. Evening, $6^{\text {th }}$ line in your manuscript:

'Die Gärten lassen zurück ihre Bäume...' In this line, after the melody, the word 'zurück' ['back'] would get an accent on the first syllable. This would be fixed if we would change: ' $z u-$ rück lassen die Gärten ihre Bäume... ${ }^{34}$.

In turn (see Fig. 3d), the writer complained that the suggested solution was:

Fig. 3a) Przyboś, Poems, ed. by Dedecius $1963^{75}$ :

Die Gär-ten ver - ie- ßen ih- re Bäu - me, grau - e Häus-chen am Fluss flos - sen

Fig. 3b) $1^{\text {st }}$ proposal by Dedecius:

Die Gär-ten las - sen zu - rück ih - re Bäu - me...

Fig. 3c) Counterproposal by Höntsch ${ }^{76}$ :

$\mathrm{Zu}$ - rück las-sen die Gär - ten ih - re Bäu - me...

Fig. 3d) $2^{\text {nd }}$ proposal by Dedecius ${ }^{77}$ :

Die Gär-ten ver - las- sen jetzt ih- re Bäu - me, grau-e Häu - ser am U - fer ver - fließen

Fig. 3e) Printed as orchestral version, E. M. 5009/ (C) $1963^{78}$ :

ist - meiner Ansicht nach - [...] die vollkommene Übereinstimmung des Wortes mit der melodischen Linie [wichtiger] als die Wahrung des Sinnes der Poesie, die übrigens jeder anders beurteilen kann'

${ }^{72}$ K. Dedecius, letter [to H. Moeck], folder Dedecius, priv. archive of Moeck, Frankfurt am Main, 16 October 1961.

${ }^{73}$ J. Przyboś, postcard [to K. Dedecius], folder Dedecius, priv. archive of Moeck, Warszawa, 2 October 1961.

${ }^{74} \mathrm{H}$. Höntsch, [carbon copy of a] letter [to K. Dedecius], folder Dedecius, priv. archive of Moeck, without place, 8 January 1962.

75 J. Przyboś, Gedichte..., op. cit., p. 15.

${ }^{76} \mathrm{H}$. Höntsch, [carbon copy of a] letter [to K. Dedecius], folder Dedecius..., op. cit.

${ }^{77}$ K. Dedecius, postcard [to H. Höntsch], folder Dedecius, priv. archive of Moeck, Frankfurt am Main, 18 January 1962 [date of receipt].

${ }^{78}$ K. Serocki, Eyes of Air. A Song Cycle for Soprano and Orchestra after Poems by Julian Przyboś, German text translation by Karl Dedecius and Witold Wirpsza, English text translation by Ann and Adam Czerniawski, Celle 1963 [and Kraków 1972], pp. 29-30.
(Dedecius/ Wirpsza:) Die Bäu-me in den Gär-ten steh’n ver - las- sen, grau-e Häu - ser am U - fer verschwommen

(A. \& A. Czerniawski:) The gar-dens have all-owed their trees to droop down, grey-ish riv - er - side hous - es have

\section{flowed on}

Fig. 3f) Printed as piano version, translated by Wirpsza, $P W M 3388 /$ ( $1959^{79}$ :

not very nice (the 'zurück' as the beginning of a sentence, as a poetic line). Maybe this is how it works:

Die Gärten verlassen jetzt ihre Bäume.

Graue Häuser am Ufer - verfließen

(but then we must also use the present tense in the next line - verfließen [to go by] - instead of verflossen [went by] $)^{80}$.

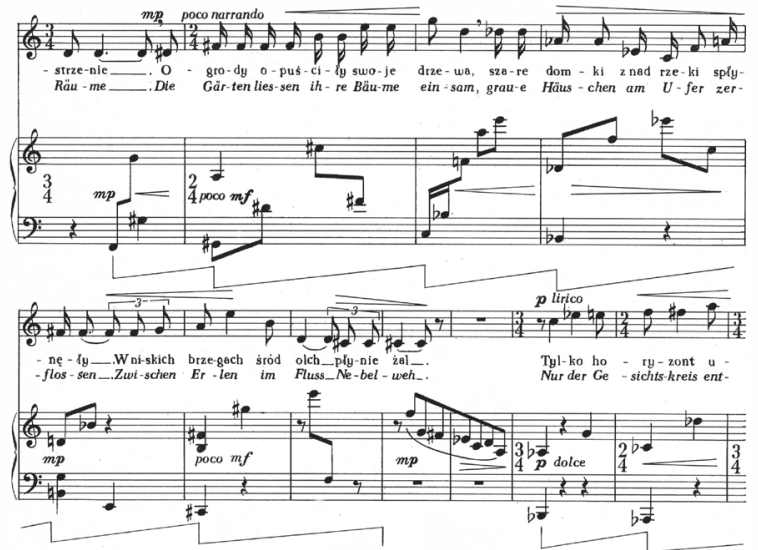

Fig. 3. Excerpt from the poem Evening by Przybos in the piano score of Eyes of Air.

Obviously, having already been critical of the composer, Dedecius added exhausted: 'Let us hope that the text can be adapted to the melody with small corrections [...]. Maybe Serocki understands and changes 2-5 notes rather than condemning the songs to death ${ }^{81}$. In the end, after these (here only hinted

${ }^{79}$ Kazimierz Serocki, Oczy Powietrza, cykl pieśni na sopran $i$ fortepian do wierszy J. Przybosia. Niemiecki przekład tekstu: W. Wirpsza, Kraków 1959, p. 14.

${ }^{80}$ K. Dedecius, postcard [to H. Höntsch], folder Dedecius..., op. cit.

${ }^{81}$ K. Dedecius, postcard [to H. Höntsch], folder Dedecius, priv. archive of Moeck, Frankfurt am Main, without date. 
at) back and forth moves, all participants agreed on a compromise that matched to the melody (see Fig. 3e, German and English version). In addition to the preparation of the German text, both of Eyes of Air and Heart of the Night, the English text underlay was also prepared at the same time. In this regard Moeck emphasized: 'We can't get along without an English translation. The German market is too small. We absolutely have to add the American market ${ }^{82}$. Because of the difficulties of the German translation, Moeck left Serocki to organize the translation himself ${ }^{83}$. But, initially Serocki couldn't find a suitable person easily. His first

'Englishman' proved to be unsound; he wrote to me that he'll not be able to do the translation of the English text of 'Eyes of Air' [...]. I hope that the matter is dealt with by the time you arrive in Warsaw. I'm embarrassed that it's taking so long, but it's bad luck ${ }^{84}$.

And the second contact, an 'attaché of the American Embassy in Warsaw, Mr. Edward Symans [...], who also worked with Lutosławski' ${ }^{85}$ and who also was taken into consideration for Szalonek's Confessions before, failed as well. Serocki only struck lucky when he persuaded the couple Ann (1926-2019) and Adam (1934-) Czerniawski, who lived in London, to take on this work. They promptly translated Eyes of Air and immediately completed the English text of Heart of the Night as well ${ }^{86}$. Serocki, who had already

${ }^{82}$ H. Moeck, [carbon copy of a] letter [to K. Serocki], folder Serocki, 5000er, priv. archive of Moeck, without place, 5 February 1960. German orig. text: 'Ohne englische Übersetzung kommen wir nicht aus. Der deutsche Markt ist zu klein. Wir müssen unbedingt den amerikanischen dazu nehmen'.

${ }^{83}$ Ibidem.

${ }^{84}$ K. Serocki, letter [to H. Moeck], folder Serocki, 5000er, priv. archive of Moeck, Warszawa, 7August 1960. German orig. text: 'Mein "Engländer" hat als unsolide erwiesen; er schrieb mir, dass er die englische Textübersetzung zu "Augen der Luft" wird nicht machen können [...] Ich will hoffen, dass bis zu Deinem Kommen nach Warschau diese Angelegenheit geregelt ist. Es ist mir peinlich, dass es so lange dauert, aber es ist eben Pech'.

${ }^{85} \mathrm{H}$. Moeck, [carbon copy of a] letter [to W. Szalonek], folder Shinohara..., op. cit., German orig. text: 'Attaché der amerikanischen Botschaft in Warschau, Herrn Edward Symans, [...] der auch für Lutosławski gearbeitet hat'.

${ }^{86} \mathrm{H}$. Moeck, [carbon copy of a] letter [to K. Serocki, concerning the completion of the English text version of Eyes of Air], folder Serocki, 5000er, priv. archive of Moeck, without place, 9 December 1960; K. Serocki, letter [to H. Moeck, concerning the completion of finished the orchestral version of the second cycle in $1960^{87}$, asked Moeck about a year later:

Concerning the printing of the score of Heart of the Night, [...] I just wanted to know whether you're [still] interested, because the validation of the contract by the Ministry and perhaps the production of the transparencies afterwards always takes quite a long time ${ }^{88}$.

In fact, Moeck had lost interest due to the long-running processes of translation and answered to this request as follows:

You are asking because of 'Heart of the Night' [...]. Actually, I'm not interested in the work anymore and that is due to the following reason: Mr. Dedecius has revised our text on 'Eye of Air. He's a nice person and it was a kindness from him. But, he's not willing to do further tasks of this kind. Under these circumstances it is better that the PWM publishes this work. If the German text isn't as good as it should be at PWM, it does not diminish the reputation of PWM in any way. The situation is different with Moeck, because it is a German publishing house ${ }^{89}$.

Since Dedecius couldn't be persuaded to translate the poems by Gałczyński again, the project failed in

the English text version of Heart of the Night], folder Serocki, priv. archive of Moeck, Warszawa, 9 July 1961.

${ }^{87} \mathrm{~K}$. Serocki, letter [to H. Moeck, i. a. concerning the work on the orchestral version of Heart of the Night], folder Serocki, 5000er, priv. archive of Moeck, Warszawa, 27 January 1960; idem, letter [to H. Moeck, i. a. concerning the completion of Heart of the Night for orchestra], folder Serocki, 5000er, priv. archive of Moeck, Warszawa, 29 May 1960.

${ }_{88}$ K. Serocki, letter [to H. Moeck], folder Serocki, 5000er, priv. archive of Moeck, Warszawa, 8 August 1961. German orig. text: 'Was das Drucken der Partitur von Herz der Nächte betrifft, so [...] wollte ich nur wissen, ob Dich das [noch] interessiert, da die Bestätigung des Vertrags durch das Ministerium und danach evtl. die Anfertigung der Transparente immer ziemlich lang dauert'.

${ }^{89}$ H. Moeck, [carbon copy of a] letter [to K. Serocki], folder Serocki, 5000er, priv. archive of Moeck, without place, 28 January 1962. German orig. text: 'Du Fragst wegen "Herz der Nächte" [...]. Ich bin eigentlich an diesem Werk nicht mehr interessiert, und zwar aus folgendem Grund: Herr Dedecius hat uns den Text zu "Augen der Luft" überarbeitet. Er ist ein netter Mann, und es war eine Freundlichkeit von ihm, aber für weitere Aufgaben dieser Art ist er nicht bereit. Unter diesen Umständen ist es besser, PWM gibt dieses Werk heraus. Wenn bei der PWM der deutsche Text nicht ganz so ist, wie er sein muß, so schmälert dieses das Ansehen von PWM in keiner Weise. Bei Moeck sieht die Sache anders aus, da er ja ein deutscher Verlag ist'. 
the end. With the permission by Moeck to use the English text version for this purpose, Serocki now offered the work to $\mathrm{PWM}^{90}$. Finally, the orchestral score was published there with the German text by Wirpsza (as PWM 5028/ ( 1963). For the production of the transparency templates PWM used a method ${ }^{91}$ the mechanics of which were further developed in the course of modernization of the printing tools, until it was patented again in 1966 (after its first conception in 1948) $)^{92}$. This offset manufacturing process was based on a manually operated printing matrix that was rolled on copy paper. From 1960 it increasingly became a component of the (foreign exchange generating) export strategy of Ars Polona and the PWM, which was also used in connection with co- and subeditions by foreign music publishers after $1966^{93}$.

Moeck's idea to offer new Polish scores as a trilingual version was targeted on a hopeful action in line with the usual Western music market conditions. That's why he also encouraged Lutosławski to provide German and English translations of his Five songs for female voice and piano (1956-57) or rather for mezzo-soprano and chamber orchestra (1958), which were composed to words by Iłłakowiczówna. Both versions were printed in Celle first (as E. M. no. 5006 and 5007/ ( 1963) and later in cooperation also produced in Cracow (as editions no. 6781/ ( 1969 and no. 6782/ (01970). Lutosławski described the character of these compositions in a comment to Moeck as

${ }^{90}$ K. Serocki, letter [to H. Moeck], folder Serocki, 5000er, priv. archive of Moeck, Warszawa, 19 January 1962.

${ }_{91}$ K. Serocki, letter [to H. Moeck], folder Serocki, 5000er, priv. archive of Moeck, Warszawa, 3 May 1961.

92 Comp. N. N., Kronika PWM 1945-1965, in: "Ruch Muzyczny" 1965 no 19 , p. 6.

${ }_{93}$ T. Ochlewski, [carbon copy of a] letter [to CHZ AP, concerning the production and the export of score prints], doc. no. 149, idem, listing [named with the title: Kalkulacja 1 str matrycy niżej podanych utworów], doc. no. 151 and idem, schedule [named with the title: Kalkulacja ustug $w$ zakresie wydawnictw nutowych], doc. no. 153, folder T225, Dyrektor Naczelny - Redakcje, Korespondencje, Centrala Handlu Zagranicznego 'Ars Polona' (1959-1961), Archiwum Państwowe w Krakowie, Ekspozytura w Spytkowicach, Kraków, 14 June 1960; S. Kisielewski, Eine Notenfabrik oder Der polnische Musikverlag, "Polen" 1963 no 3, p. 28.; M. Tomaszewski, Plany-perspektywypobożne życzenia, "Ruch Muzyczny" 1965 no 19; Musikalischer Vermittler. Gespräch mit Mieczyslaw Tomaszewski. Direktor des Polnischen Musikverlags in Krakau, "Polen" 1966 no 4, p. 44. a study [...] whose line of the melody is defined by a continuous moving harmonic background, based on chords that lean on the entire 12-tone scale. The composer models the structure of these chords [...] [,] their own expressiveness, in such a way that he achieves a [...] musical expression resulting from the text $\mathrm{t}^{94}$.

However, firstly 'the translations by the poet herself [were] not applicable to me. They don't match the rhythm of my songs at all'95, and then also the work by Wirpsza 'particularly in linguistic terms, but also in terms of ensuring the poetic meaning of the poems [...] [had] shortcomings ${ }^{96}$. After the composer had already asked Moeck ironically, if he didn't think 'it would be more comfortable, if I compose a vocal piece after a Latin text next time?'97, the publisher turned to Dedecius again. The specialist, who gladly would have done Lutosławski the favour because he knew him personally ${ }^{98}$, agreed at first. But then, after the matter rested for a while, he admitted that he failed, too:

I warned you [...]. It was already difficult to give the Przyboś texts meaning and form in German, so it was almost impossible with Madame I., whose [...] kind of lullaby and fabulous poetry is not in me at all. And you asked me for a prose translation. Also, this had to fail because we don't know this poetic intonation in German. Poles are moved [emotionally]

94 W. Lutosławski, letter [to H. Moeck], folder Lutosławski, Marco, 5000er, priv. archive of Moeck, Warszawa, 14 January 1961. German orig. text: 'Die Linie der Melodie wird durch einen fortwährenden beweglichen harmonischen Hintergrund, angelehnt an Akkorde, die die gesamte 12-Ton-Skala umfassen. Die Struktur dieser Akkorde [...] [,] ihre eigene Ausdruckskraft modelliert der Komponist so, daß er den [...] sich aus dem Text ergebenden musikalischen Ausdruck erreicht'.

95 W. Lutosławski, letter [to H. Moeck], folder Lutosławski, priv. archive of Moeck, Warszawa, 3 February 1960. German orig. text: '[...] die Übersetzungen von der Dichterin selbst [waren] für mich selbst nicht anzuwenden. Zu dem Rhythmus meiner Lieder passen sie gar nicht'.

${ }^{6}$ H. Höntsch, [carbon copy of a] letter [to W. Lutosławski], folder Lutosławski, priv. archive of Moeck, without place, 24 August 1961. German orig. text: 'insbesondere in sprachlicher Hinsicht, aber auch im Hinblick auf die Wahrung des poetischen Sinns der Gedichte [weist] Wirpszas Übersetzung [...] Mängel auf[weist]'.

${ }_{97}$ W. Lutosławski, letter [to H. Höntsch], folder Lutosławski, priv. archive of Moeck, without place, 23 April 1960. German orig. text: 'Glauben Sie nicht, dass es für uns viel bequemer wäre, wenn ich das nächste Vokalstück nach einem lateinischen Text komponiere?'

98 K. Dedecius (see fn. no 81). 
by such things, we [Germans] are embarrassed. There is nothing one can $\mathrm{do}^{99}$.

Afterwards Moeck tried a Hamburg translator Valentin Polcuch (1911-1989) - but without any more success. Finally, Moeck even gave up publication of the Five songs with a German text. And, even though the cycle was published in a Polish-English version it wasn't possible to find an adequate translation, consisting of appropriate choice of words, faithful rendering of the poetic meaning and conformity to the rhythmic-melodic parameters. After an employee of the American Embassy finished his translation for the pieces, Lutosławski signalled to Moeck that

[t] he whole translation story of my songs makes me laugh. [...] [S] omething new has come along, to complicate the matter once more for us: Mrs. Iłłakowicz has just written that she thinks the translation is very bad. 'Apparently, he didn't understand my poetry at all' - she writes ${ }^{100}$.

So the search went on, and ended only when Serocki recommended the Czerniawskis to take on the translation of these songs, too. As it happened with the two pieces by Serocki, this vocal cycle was also finally published in 1963. In contrast to Serocki, Lutosławski decided against a further and deeper cooperation with this publishing house due to the difficulties described here. Also striking is the fact that after this Lutosławski wrote new French-based vocal works such as Trois poèmes d'Henri Michaux for choir and orchestra (1961-63) and Paroles Tissées for tenor and

${ }^{99}$ K. Dedecius, postcard [to H. Höntsch.], folder Dedecius, priv. archive of Moeck, Frankfurt am Main, 10 August 1962 [date stamp]. German orig. text: 'Ich hatte Sie gewarnt [...]. War es schon schwierig, dem Przyboś-Text Sinn und Gestalt im Deutschen zu geben, so war dieses bei Madame I., deren [...] wiegenliedartige und märchenhafte Poesie mir gar nicht liegt, schier unmöglich. Und Sie baten um eine Prosa-Übersetzung. Auch das mußte mißlingen, weil wir im Deutschen diese poetische Intonation nicht kennen. D[ie] Polen rührt so etwas [emotional], uns [Deutsche] stimmt es verlegen. Da ist nichts zu machen'

${ }^{100}$ W. Lutosławski, letter [to H. Moeck], folder Lutosławski, priv. archive of Moeck, Warszawa, 20 May 1960. German orig. text: 'Die ganze Geschichte der Übersetzungen meiner Lieder begint [sic!] mich zum Lachen zu bringen. [...] [E]s ist etwas Neues hinzugekommen, um uns die Sache noch einmal zu [ver]komplizieren: Frau Iłłakowicz schreibt mir eben, dass sie die Übersetzungen von Symans als ganz schlecht findet. "Offensichtlich hat er meine Gedichte gar nicht verstanden» - schreibt sie'. chamber orchestra (1965) to words by Jean-François Chabrun (1920-1997). It is conceivable that this had a direct connection to his unpleasant experiences with the German and English translations of the Five Songs. It could also be that since Lutosławski had extensive knowledge of French he was therefore able to assess this language better. After Höntsch asked for the orchestral formation of the new piece and offered to take his Trois poèmes under contract ${ }^{101}$, he was open to composing for two conductors. Hereupon Höntsch reacted too reticently, when he said: 'Nevertheless, I cannot keep to myself the thought that two conductors for one piece, according to general experience, is not exactly ideal for relatively easy distribution of the work $^{102}$. After hearing this Lutosławski increasingly kept his distance from Moeck and from then on started thinking about another internationally well-connected alternative.

\section{CONCLUSION}

The article answers the question of what happens when an iron curtain stands in between when a West German music publisher distributes Polish contemporary music, with an interdisciplinary perspective on what happened. In addition to music-historical, music-sociological and music-analytical approaches and taking cultural transfer research into account, the author also takes a transcultural perspective. This not only reveals and describes interpersonal encounters, such as those between the composers and Moeck from 1958 to 1967, which led to common actions and goals. Cultural encounters, such as those that exist with regard to the translation work of Polish prose and with regard to the complex link between music and language, can also be fathomed out in this way. Because the interpersonal as well as the cultural aspect occupy an important position here, the duality of the article is derived from it.

${ }^{101} \mathrm{H}$. Höntsch, [carbon copy of a] letter [to W. Lutosławski], folder Lutosławski, priv. archive of Moeck, without place, 11 February 1963.

${ }^{102} \mathrm{H}$. Höntsch, [carbon copy of a] letter [to W. Lutosławski], folder Lutosławski, priv. archive of Moeck, without place, 4 March 1963. German orig. text: 'Trotzdem aber kann ich es nicht für mich behalten, daß zwei Dirigenten für ein Stück nach den allgemeinen Erfahrungen nicht sehr ideal sind im Hinblick auf eine verhältnismäßig leichte Verbreitung des Werkes' 
When the PRL opened its borders after 1956 and the Polish music scene came back into active contact with foreign countries, the West German musical life also came into focus. There are two factors that have contributed to this development: on the one hand, there were decisive changes in cultural policy in the Federal Republic of Germany in 1945 and, on the other hand, after 1956 in the People's Republic of Poland too. As a result, also musicians gained new artistic freedom and professional perspectives, which encouraged a lively exchange with international musical life. When Poland took part in the Darmstadt summer courses for the first time from 1957 and West Germans regularly took part in the Warsaw Autumn from 1958, the musical-cultural dynamics and the progressive mood of both sides met. Both sides were looking for something new and started cooperation beyond the ideological and territorial borders of the East-West conflict. This circumstance was of great importance for the international reputation of contemporary Polish composers and their works in the 1960s. The participation in Western musical life was also an expression of compensation for the formerly restrictive Stalinist cultural policy.

The article suggests that the participation in West German musical life between 1957 and 1967 - apart from renowned transnational music forums such as Darmstadt and Donaueschingen - extended much further than is shown in current music research. The repertoire of the above-mentioned circle of composers was much more integrated than has been described so far. It is well-known that the major West German broadcasters, who also regularly commissioned composers such as Górecki, Kotoński, Lutosławski, Penderecki and Serocki etc., played an important role in this. In the 1960s, Polish new music was regularly integrated into one of the numerous concert series that were distributed throughout the Federal Republic. On the other hand, the function and role of West German music publishing houses is largely unknown. In fact, the 'background work' carried out here has also contributed to the international spread of (contemporary) Polish music culture and the reputation of the aforementioned circle of composers 'in the West'. As illustrated, a considerable number of concert performances of Polish contemporary music took place in the cultural life of the
Federal Republic between 1957 and 1967, thanks to the commitment of the radio stations and the music publishers.

As could be shown, personal contacts between the cultural actors, who generally had an influential music institution behind them, were especially important for mutual cooperation. When the composers in the ZKP got to know Hermann Moeck in 1958, this circumstance was also of importance. The music publisher was well networked in Germany and also in personal contact with the PWM director Tadeusz Ochlewski, for example. Moeck appeared rather by chance at the right time, when he was awarded the contract for his offer to represent the performance materials and scores published by PWM in Western countries. Documents not specified here show that this task did not necessarily have to be performed by a West German publisher. In the search for exclusivity, however, Moeck was most likely to meet the ambitions of the composers, who at that time had already envisaged a systematic distribution of their works in the West'. In addition, it corresponded to the new cultural policy line in the MKiS, which at that time not only ordered the modernization of the PWM, but, together with the MHZ and its subordinate foreign trade center Ars Polona, also initiated a strategy for the import and export of music and sheets. At that time, however, the structures of Polish foreign trade were still in a phase of development and organization. PWM didn't publish adequate contemporary music sheets until the early 1960s, and foreign trade in music didn't function until the mid-1960s. Accordingly, the composers were lucky to find another very committed patron in Moeck, who distributed their works in the West of Germany and Europe. This happened not only through the Musica Polona Edition, which he founded together with his Polish business partners Ars Polona and PWM. With the founding of the company's own Edition Moeck, he also campaigned directly for the promotion of Polish music culture 'in the West' - in particular to place the new works of Penderecki, Serocki and Kotoński, but also those of Bacewicz, Baird and Lutosławski on the international music market. Because the Edition Moeck contradicted the previous agreements with the MKiS in a certain way - the Moeck-Verlag held the exclusive rights with it - a conflict arose in the early 
1960s with regard to the production and distribution of performance materials in Germany or in Poland and the associated handling of copyright. The plan to circumvent the lengthy and unpleasant communication and dispatch routes (via Ars Polona) ultimately revealed the different interests of all involved parties. As a result, the dispute on the Polish side even resulted in a ban on publishing other Polish works abroad in 1963. At that time, the socialist leadership feared that the cultural (as well as financial) successes of the native composers would pass by the state and that it would lose control of national cultural life. In addition to this cultural-political ambition, however, trade-political factors were also important, which were aimed at obtaining foreign exchange for the state budget. However, it can be assumed that sheet music had only a very small share of such foreign exchange receipts and was thus intrinsically insignificant. Both Moeck and PWM earned almost nothing from the sale of contemporary score editions. Nevertheless, the composers (represented institutionally by a very self-confident ZKP), who did not want to lose their newly gained scope for action after 1956 (also with regard to Western countries), were hit by the ban at a very sensitive point. What followed was a longer negotiation process, in which Moeck, the composers in the ZKP, the PWM, the ZAiKS, Ars Polona and the respective higher authorities, the $\mathrm{MHZ}$ and the MKiS, were involved until 1966. As a result, the copyright was now divided into the spheres of influence of the East-West conflict, which wasn't a solution of the problem in a true sense. However, from 1966 onwards, cross-border cooperation and forwarding agreements with business partners abroad were approved, which made it possible to cooperate with major Western publishing houses such as Chester, C.F. Peters and Schott. Although Moeck at that point lost his unique selling point as the only distributor of Polish works 'in the West', this step further extended the professional scope of the composers on an international level - more than before the dispute. This underpins both the example of Penderecki's collaboration with the publishing house of Schott from 1966 and the example of Lutosławski's cooperation with Chester from 1966. Because of this step, the opportunities on the Western European and now also on the US music market increased significantly.
Hermann Moeck's decision to translate Polish lyrical texts into German and English and to publish them as a trilingual version needs also to be seen against the background of greater opportunities for Polish contemporary works on the Western music market. In fact, both the music publisher and the composers significantly underestimated the associated effort and the project reached its limits. For this reason, we can certainly speak here of a 'failed cultural transfer' from East to West in some respects. It was simply too difficult to find suitable translators. In addition, the costs were high and the result (apart perhaps from Serocki's Eyes of Air) too unsatisfactory. The translation of Polish poetry texts under the simultaneous consideration of melodic and rhythmic criteria in the music was therefore too complex. Text and music samples in this article have illustrated this. Although there is no proof of this, the hypothesis suggests that Lutosławski used French in subsequent vocal works on the basis of this experience.

In conclusion, it should be noted that the 'early' collaboration between the mentioned composers and Moeck from 1958 to 1966 was a remarkable bridge-building process - not only regarding the Cold War conditions, but also for the Polish-German or German-Polish relations at that time. It arose in an atmosphere of new (cultural) beginnings on both sides and mutual interest to advance Polish contemporary music within the Western German and European musical life. Although financial aspects certainly played a role, the focus was primarily on cultural ambitions. At the same time, the achievements of the mentioned composers abroad played into the hands of the Polish cultural policy in the 1960s, which was keen to use this opportunity to create a positive (music) cultural image in Western countries. In fact, however, and though the international distribution of Polish contemporary music also by Moeck was an important part of raising the worldwide reputation during the early 1960s, this subject has hardly been considered in music research so far. This also applies to the role of other music publishing houses like Chester or even the publishing work by the PWM. It could certainly be a worthwhile and insightful research project to understand the interrelationships concerning the participation of Polish contemporary composers in Polish and international musical life in the period discussed here. 


\section{BIBLIOGRAPHY}

\section{Journal, newspaper and anthology articles}

Będkowski Stanisław, Serie dźwiękowe w twórczości Kazimierza Serockiego, "Muzyka" 1996 vol. 41 no 1, pp. 3-39.

Będkowski Stanisław, Zmienne metra w twórczości Kazimierza Serockiego, "Muzyka" 1996 vol. 41 no 4, pp. 15-25.

Borchers Sebastian, Von Warschau nach Darmstadt und zurück. Lutosławski, Penderecki, Górecki und die Neue Musik, "Osteuropa" 2012 vol. 62 no 11-12, pp. 73-84.

Borchers Sebastian, Wglad do polsko-niemieckiej relacji w muzyce współczesnej w sześćdziesiątych i siedemdziesiątych latach, [in:] W kregu kultury PRL. Muzyka. Konteksty, ed. Dorota Skotarczak and Karolina Bittner, Wydawnictwo Naukowe UAM, Poznań 2016, pp. 79-90.

Brachmański Teodor, O eksporcie płyt gramofonowych, "Ruch Muzyczny" 1962 no 15, pp. 3-4.

Deutsche Presse-Agentur GmbH, Kunstpreis des Landes NRW. Zu den Ausgezeichneten gehören zwei Ausländer, [in:] "Kölner Stadtanzeiger”, 21 July 1966, p. (not specified, unknown).

EMI, Philips Deal Disks with Poland, "Billboard. The International Music-Record Newsweekly” 70, 18 January 1964, p. 20.

Gwizdalanka Danuta, Lutosławski. Błędy i legendy, "Ruch Muzyczny” 2013 no 19, pp. 38-42.

Harder Jeannine, Polnische Filmplakate aus transnationaler Sicht. Die Wurzeln der "Polnischen Schule der Plakatkunst" in den 1950er Jahren, "Comparativ" 2014 vol. 24 no 4, pp. 58-67.

Higher Each Year. Exports of Polish Disks Make Gain, "Billboard. The International Music-Record Newsweekly" 70, 11 July 1964, p. 6.

Höntsch Herbert, Polonia Edition im Hermann Moeck Verlag. Musiktransfer von Ost nach West. Anmerkungen eines Insiders, [in:] Sine musicae nulla vita. Festschrift Hermann Moeck zum 75. Geburtstag, ed. Nikolaus Delius, Moeck Verlag, Celle 1997, pp. 37-43.

Jaźwińska Zofia, Problemy eksportu muzyki polskiej, "Ruch Muzyczny" 1963 no 5, pp. 19-20.

Kisielewski Stefan, Eine Notenfabrik oder Der polnische Musikverlag, "Polen" 1963 no 3, pp. 26-29.

Kronika PWM 1945-1965, "Ruch Muzyczny” 1965 no 19, pp. 6-7.

Lissa Zofia, Analiza repertuaru "Warszawskich Jesieni", "Muzyka" 1969 vol. 14 no 3, pp. 40-66.

Musikalischer Vermittler. Gespräch mit Mieczyslaw Tomaszewski. Direktor des Polnischen Musikverlags in Krakau, "Polen” 1966 no 4, pp. 45-45.
Mycielski Zygmunt, Walne Zgromadzenie Związku Kompozytorów Polskich, "Ruch Muzyczny” 1963 no 5, pp. 1-2.

Tomaszewski Mieczysław, Plany - perspektywy - pobożne $\dot{z} y$ czenia, "Ruch Muzyczny" 1965 no 19, pp. 4-6.

Waschko Roman, Brachmanski to West for Talks, "Billboard. The International Music-Record Newsweekly" 69, 23 November 1963, p. 37.

Waschko Roman, Polish Company Sets Disk Trade Deal With Columbia, "Billboard. The International Music-Record Newsweekly" 69, 23 November 1963, p. 32.

Zathey Janusz, Darmstadt "Mekka Nowej Muzyki", "Ruch Muzyczny" 1957 no 12, pp. 9-13.

Zathey Janusz, Darmstadt "Mekka Nowej Muzyki", "Ruch Muzyczny"1957 no 13, pp. 25-28.

\section{Bulletins and catalogues}

Aus dem Polnischen Musikverlag Krakau. Neuerscheinungen, in: Moeck Information, ed. Moeck Verlag und Musikinstrumentenwerk, Celle, September/1978, pp. 1-2.

International Copyright Union. Bern Convention 1886, Paris Convention 1896, Berlin Convention 1908, [in:] Copyright Bulletin, no. 13, ed. Library of Congress, Washington 1908, pp. 5-59.

Musica Polona Edition. Eine Auswahl aus dem polnischen Musikschaffen bis zur Gegenwart und anderen Ausgaben des Polnischen Musikverlags, ed. Hermann Moeck Verlag, Celle 1959.

Orchestermusik, ed. Hermann Moeck Verlag, Celle 1959.

Orchestermusik moderner polnischer Komponisten. Reversmaterialien, ed. Hermann Moeck Verlag, Celle (probably 1958).

\section{Publications}

Cichy Daniel, Internationale Ferienkurse für Neue Musik $w$ Darmstadcie. Dzieje, rola i znaczenie $w$ myśli teoretycznej, praktyce kompozytorskiej i życiu muzycznym drugiej połowy XX wieku, Musica Iagellonica, Kraków 2009.

Haltof Marek, Historical Dictionary of Polish Cinema, second edition, Rowman \& Littlefield, Lanham 2015.

Lindstedt Iwona, Dodekafonia i serializm w twórczości kompozytorów polskich XX wieku, Polihymnia, Lublin 2001.

Lüsebrink Hans-Jürgen, Kulturtransfer - methodisches Modell und Anwendungsperspektiven, [in:] Europäische Integration als Prozess von Angleichung und Differenzierung, ed. Ingeborg Tömmel, Leske-Budrich, Opladen 2001.

Paja-Stach Jadwiga, Polish Music from Paderewski to Penderecki, Musica Iagellonica, Kraków 2010.

Przyboś Julian, Gedichte, translated by Karl Dedecius, Langewiesche-Brandt, Ebenhausen bei München 1963. 
Schmidt-Rost Christian, Jazz in der DDR und Polen Geschichte eines transatlantischen Transfers, Peter Lang, Frankfurt am Main 2015.

Seehaber Ruth, Die "polnische Schule" in der Neuen Musik. Befragung eines musikhistorischen Topos, ed. Detlef Altenburg, Böhlau Verlag, Köln-Weimar-Wien 2009.

Thomas Adrian, Polish Music since Szymanowski, Cambridge University Press, Cambridge 2005.

Walter Veronika, Schritte zur Normalität. Die deutsch-polnischen Kulturbeziehungen Bestandsaufnahme und Empfehlungen, ed. Institut für Auslandsbeziehungen e.V., ifa Dokument 2003 vol. 1.

Witold Lutosławski. Correspondence with his Western Publishers and Managers 1966-1994, ed. Zbigniew Skowron, vol. 1, Musica Iagellonica, Kraków 2019.

\section{Online media}

Chronic of the Summer Courses Darmstadt 1946-1966, ed. International Music Institute, online available: https:// internationales-musikinstitut.de/content/uploads/ imd-1946-66chronikdarmstaedterferienkurse.pdf (publication date: unknown; date of access: 25.04.2020).

Dąbek Karolina, Cykl pieśni “Oczy powietrza” Kazimierza Serockiego. Próba interpretacji. Online available: http:// meakultura.pl/publikacje/cykl-piesni-oczy-powietrzakazimierza-serockiego-proba-interpretacji-1388(publication date: 27 November 2015; date of access: 25.04.2020).

HarderJeannine, PolnischePlakatkunstalsMediumtransnationaler Kunstkontakte und Kulturpolitik im Ost-West-Konflikt, [in:] Themenportal Europäische Geschichte, 2015, online available: www.europa.clio-online.de/essay/id/fdae1656 (3.07.2020).

\section{Interview}

Borchers Sebastian, A Conversation with Hermann Moeck and Herbert Höntsch [unpublished sound recording], Celle 2009.

\section{Scores}

Kotoński Włodzimierz, Concerto per Quattro for Harp, Harpsichord, Guitar, Piano and Chamber Orchestra (1965), ed. Elżbieta Widłak, PWM, Kraków 1966.

Penderecki Krzysztof, Passio et mors Domini Nostri Iesu Christi Secundum Lucam (1965), Moeck and PWM, Celle and Kraków 1967.

Serocki Kazimierz, Eyes of Air. A Song Cycle for Soprano and Orchestra after Poems by Julian Przyboś, German text translation by Karl Dedecius and Witold Wirpsza, English text translation by Ann and Adam Czerniawski, Moeck Verlag, Celle 1963.

Serocki Kazimierz, Oczy powietrza, cykl pieśni na sopran $i$ fortepian do wierszy J. Przybosia. Niemiecki przekład tekstu: Witold Wirpsza, PWM, Kraków 1959.

Przykład nutowy wykorzystany w artykule: Eyes of the Air Music by Kazimierz Serocki

Text by Julian Przyboś

Copyright $\odot 1957$ (Renewed 2006) by Mannheimer Musikverlag (part of G. Ricordi \& Co. Buehnen- und Musikverlag GmbH)

All Rights Reserved. International Copyright Secured

Reproduced by kind permission of Hal Leonard Europe Srl obo G. Ricordi \& Co. Buehnen- und Musikverlag GmbH

\section{SUMMARY}

\section{Sebastian Borchers}

\section{Polish Music Published by Moeck 1958 to 1967 - a (Failed?) Transfer from East to West}

From the end of the 1950s, the West German publisher Moeck officially represented the state-led music publishing house PWM 'in the West' with the permission of the Polish Ministry of Culture. Beside the distribution of score editions and orchestral performance materials by the PWM, Moeck also represented the interests of Polish composers in the Federal Republic of Germany directly in his own catalogue. Among the first authors of the new series of editions were Kotoński, Lutosławski, Penderecki, Serocki and Szalonek. They belonged to a circle that regularly participated in West German musical life in the 1960s. Despite the spirit of optimism and advantages for the composers, this cooperation also led to problems on several levels. These included the billing of performance materials and the handling of international copyright. This made the participants aware of various limits and led to conflicts especially on the Polish side. Translation of Polish texts in vocal works into German and English was also not as straightforward as originally planned. The article offers new insights into Polish-German cooperation in the cultural field of music, which went on despite the difficult relationship between the two states then and also beyond the borders of the Cold War.

\section{Keywords}

Cold War, contemporary music, copyright, cultural transfer, Moeck, music publishing, translation 